\title{
Basaltic feeder dykes in rift zones: geometry, emplacement, and effusion rates
}

\author{
I. Galindo ${ }^{1}$ and A. Gudmundsson ${ }^{2}$ \\ ${ }^{1}$ Spanish Geological Survey (IGME), Unit of Canary Islands, Alonso Alvarado, 43, $2^{\circ} \mathrm{A}$, Las Palmas, 35003, Spain \\ ${ }^{2}$ Department of Earth Sciences, Royal Holloway University of London, Egham, TW20 0EX, UK
}

Correspondence to: I. Galindo (i.galindo@igme.es)

Received: 26 July 2012 - Revised: 28 October 2012 - Accepted: 10 November 2012 - Published: 18 December 2012

\begin{abstract}
Most volcanic hazards depend on an injected dyke reaching the surface to form a feeder. Assessing the volcanic hazard in an area is thus related to understanding the condition for the formation of a feeder dyke in that area. For this latter, we need good field data on feeder dykes, their geometries, internal structures, and other characteristics that distinguish them from non-feeders. Unfortunately, feeder dykes are rarely observed, partly because they are commonly covered by their own products. For this reason, outcrops are scarce and usually restricted to cliffs, ravines, and man-made outcrops. Here we report the results of a study of feeder dykes in Tenerife (Canary Islands, Spain) and Iceland, focusing on their field characteristics and how their propagation is affected by existing structures. Although Holocene fissure eruptions have been common in both islands, only eleven basaltic feeder dykes have been identified: eight in Tenerife and three in Iceland. They are all well preserved and the relation with the eruptive fissure and/or the deposits is well exposed. While the eruptive fissures are generally longer in Iceland than in Tenerife, their feeders show many similarities, the main ones being that the feeder dykes (1) are generally sheet-shaped; (2) are segmented (as are the associated volcanic fissures); (3) normally contain elongated (prolate ellipsoidal) cavities in their central, topmost parts, that is, $2-3 \mathrm{~m}$ below the surface (with solidified magma drops on the cavity walls); (4) contain vesicles which increase in size and number close to the surface; (5) sometimes inject oblique dyke fingers into the planes of existing faults that cross the dyke paths; and (6) may reactivate, that is, trigger slip on existing faults. We analyse theoretically the feeder dyke of the 1991 Hekla eruption in Iceland. Our results indicate that during the initial peak in the effusion rate the opening (aperture) of the feeder dyke was as wide as $0.77 \mathrm{~m}$, but quickly decreased to
\end{abstract}

about $0.56 \mathrm{~m}$. During the subsequent decline in the effusion rate to a minimum, the aperture decreased to about $0.19 \mathrm{~m}$. At a later abrupt increase in the effusion rate, the feeder-dyke opening may have increased to about $0.34 \mathrm{~m}$, and then decreased again as the effusion rate gradually declined during the end stages of the eruption. These thickness estimates fit well with those of many feeders in Iceland and Tenerife, and with the general dyke thickness within fossil central volcanoes in Iceland.

\section{Introduction}

All volcanic eruptions on Earth are fed by conduits through which magma is transported from a source chamber to the surface. Magma conduits may be cylindrical, such as the main vents of Etna, Stromboli and Reunion, or tabular or sheet-like, such as many that feed fissure eruptions in rift zones in the USA, Japan, the Canary Islands and Iceland (e.g., Pollard et al., 1983; Delaney and Gartner, 1997; Gudmundsson, 2002; Acocella and Neri, 2003; Gudmundsson et al., 2008; Keating et al., 2008; Poland et al., 2008; Geshi et al., 2010, 2012). The solidification of magma inside these conduits forms plugs and feeder dykes, respectively. Many plugs, however, are composed of dense clusters of dykes (Gudmundsson, 2012a). In rift zones, magma conduits are usually tabular or sheet-like subvertical dykes, and when they reach the surface they form eruptive fissures whose trends coincide with those of the associated feeder dykes. If magma in a sheet-like conduit does not reach the surface, the structure is referred to as an arrested dyke.

While arrested dykes are commonly observed in eroded parts of volcanic edifices, observed feeder dykes are rare 
(Gudmundsson, 1986, 2002; Marinoni and Gudmundsson, 2000; Geshi et al., 2010, 2012). Some feeder dykes have been reported from Iceland, Italy, USA, Japan and the Canary Islands (Saemundsson, 1967; Jonsson, 1978; Atkinson and Lambert, 1990; Gudmundsson, 1986, 2002; Goto et al., 1990; Rickwood, 1990; Galindo, 2005; Gudmundsson et al., 2008; Keating et al., 2008; Geshi et al., 2010, 2012). Theoretical studies suggest that, on approaching the surface, feeder dykes should normally become thicker and shorter (Gudmundsson, 1986; Maaloe, 1998; Gudmundsson et al., 2008; Keating et al., 2008). This is supported by field observations of many feeders (e.g., Gudmundsson et al., 2008; Keating et al., 2008; Geshi et al., 2010, 2012). Some feeder dykes have been studied to depths of a few hundred metres below the surface (e.g., Gudmundsson et al., 2008; Keating et al., 2008; Geshi et al., 2010, 2012), but few feeders have been studied in great detail as regards changes in their geometry, internal structure, and texture on approaching the surface. Such studies are needed because of the importance of understanding feeder dykes when assessing volcanic hazards and risks. For example, feeder dykes provide information on: the mechanical properties of the host rocks and the stress conditions that encourage a dyke to reach the surface, magma overpressure and flow direction at the time of dyke emplacement, magma cooling and degassing processes near the surface, the physical transition from the dyke itself to its deposits, the locations of the intersections between the dyke and the free surface, and the mechanism and mechanics of the eruptive-fissure propagation.

In this paper we report the results of a detailed study of several well-exposed feeder dykes in the rift-zones of Tenerife (Canary Islands) and Iceland. We discuss a total of 11 feeder dykes; 8 in Tenerife and 3 in Iceland. While all the dykes come from two areas, Tenerife and Iceland, feeder dyke formation, like fracture formation in general, has many common characteristics with implications for other areas. Thus, we compare our results from Iceland and Tenerife with results on feeder dykes in other areas, in particular data on feeder dykes in Japan.

In Tenerife, the feeder dykes are observed along the three rift zones of the island where landslides, intense erosion, and quarries make it possible to study the feeders in detail. The exposures of the feeder dykes are excellent but of limited sizes, mostly restricted to a few tens of metres below the surface. The outcrops in Iceland are generally larger and occur in canyons formed by large floods in rivers or cliffs generated by sea erosion. The studied feeder dykes are all well preserved and their relationship with the eruptive fissure and the erupted deposits are well exposed.

The principal aim of the paper is to present a detailed description of feeder dykes and their connections with the associated volcanic fissures so as to improve our understanding of feeders and provide accurate field data for mechanical models of dyke emplacement and hazard assessments. A second aim is to analyse the volumetric flow rate through a

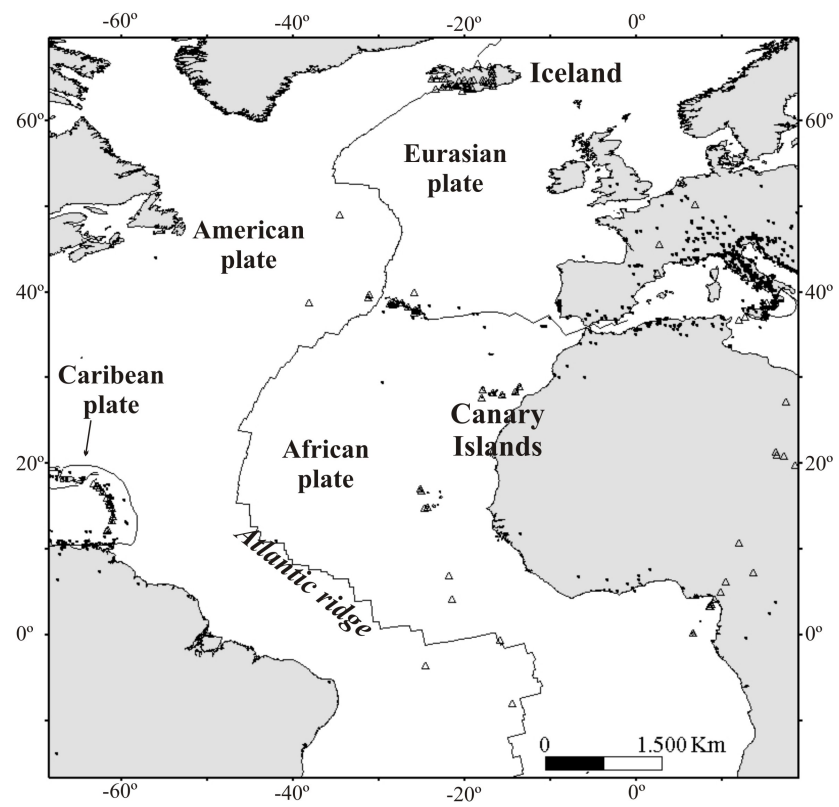

Fig. 1. Volcano-tectonic settings of Iceland and the Canary Islands.

typical feeder dyke. All the feeder dykes studied in the field are well exposed but emplaced long before any volcanological monitoring began. The volumetric flow-rate data must come from a comparatively recent and well-monitored eruption. Here we use data from the well-documented 1991 Hekla eruption in Iceland and relate the variation in the associated volumetric flow or effusion rates with variations in the opening (aperture or thickness) of the feeder dyke.

\section{Volcano-tectonic setting}

Iceland and Tenerife are both volcanic islands but they are located in somewhat different volcano-tectonic settings (Fig. 1). Iceland constitutes the subaerial part of the MidAtlantic Ridge, where the Eurasian plate diverges from the North American plate at a rate of around $20 \mathrm{~mm} \mathrm{yr}^{-1}$ (García et al., 2003). In contrast, Tenerife is part of the Canary Islands archipelago that is located inside the African Plate, which is considered stationary or moving very slowly (Burke and Wilson, 1972; Burke, 1996; O'Connor et al., 1999). However, both islands are widely thought to be related to mantle plumes. The plume under Iceland is well confirmed and has been traced to depths of at least $400 \mathrm{~km}$ (Wolfe et al., 1997; Bjarnason, 2008). As for the Canary Islands, the existence of a mantle plume is more debated, but many have related their volcanism to a mantle plume activity (e.g. Hoernle and Schmincke, 1993; Carracedo et al., 1998; Duggen et al., 2009). Both the volcanic islands have developed rift zones (Fig. 2). Rift zones form when the intrusion of magma takes place within a restricted area, a zone, where the stress field is essentially uniform and thus encourages the generation of 

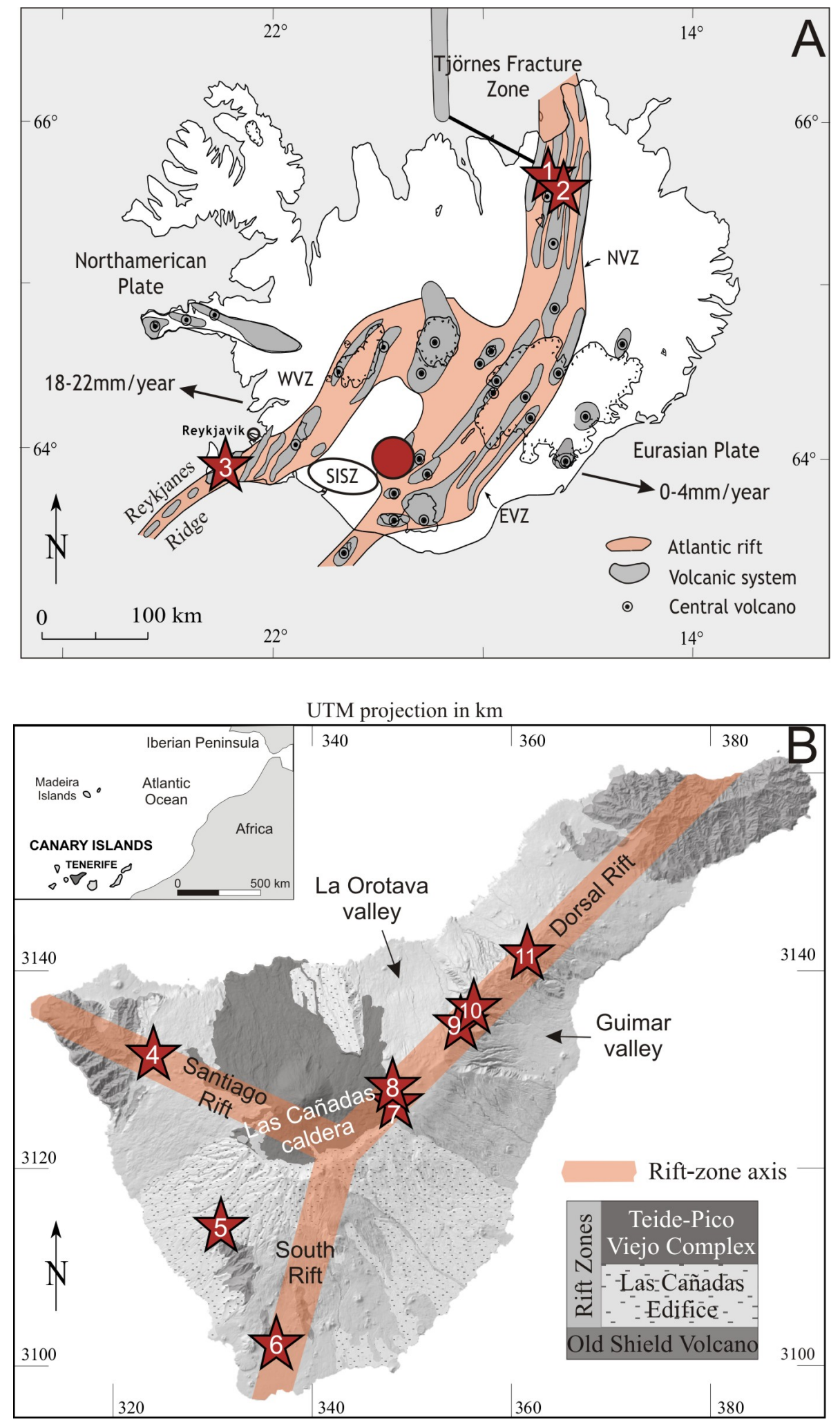

Fig. 2. Simplified geological maps of Iceland (A) and Tenerife (B) showing the location of the active rift zones (in orange) and the studied feeder dykes (red stars). The numbers indicate the name of the feeder dykes: (1) Hljodaklettar; (2) Raudholar; (3) Reykjanes; (4) Llanos; (5) Infierno; (6) Cho; (7) Colmenas; (8) Chiqueros; (9) Negrita; (10) Colorada; (11) Chese. Also shown is the location of the Hekla Volcano (red filled circle), the 1991 volcanic eruption (and associated feeder dyke) of which are analysed in the paper. The inset map in (B) shows the location of the Tenerife Island. 
swarms of sub-parallel dykes injected perpendicular to the maximum tensile (minimum compressive) principal stress, $\sigma_{3}$. Dykes in rift zones coexist with other extensional structures such as tension fractures, normal faults, and grabens, most of which trend parallel with the rift-zone axis (e.g., Rubin and Pollard, 1988; Gudmundsson, 2002; Galindo, 2005; Galindo et al., 2005; Klügel et al., 2009).

Volcanic activity in a rift zone is characterised by fissure eruptions. The fissures are fed by those dykes that are able to propagate from their source chambers to the surface, that is, feeders. Feeder dykes are rarely exposed, partly because they are normally covered by their own eruption products. Basaltic fissure eruptions are common in Iceland and Tenerife. However, and as a result of their different tectonic situation, the fissures are more frequent and longer, on average, in Iceland. The longest Holocene volcanic fissures in Iceland reach about $70 \mathrm{~km}$, and several tens-of-kilometers fissures have erupted in historical time (the past $1100 \mathrm{yr}$ ). In Tenerife, the last fissure eruption took place in 1909 (Chinyero eruption) and is, like most other eruptive fissures in the island, only several hundred metres long (Galindo, 2005). The longest eruptive fissure in Tenerife is less than $4 \mathrm{~km}$ long (Galindo, 2005; Galindo et al., 2005).

In this study, one primary focus was on finding good outcrops of feeder dykes in the field. As a result, a total of eleven feeder dykes were identified along the rift zones of Iceland and Tenerife (Fig. 2). In Iceland, three Holocene feeder dykes were studied, namely the feeders of the lava flows of (Fig. 2a) Hljódaklettar (1) and the Raudhólar (2) in the North Volcanic Zone, and of Stampar (3) in the West Volcanic Zone. In Tenerife eight feeder dykes have been identified (Fig. 2b), namely the Llanos feeder dyke (4) in the Santiago Rift, the Infierno (5) and Cho (6) feeder dykes in the South Rift, and the Colmenas (7), Chiqueros (8), Negrita (9), Colorada (10) and Chese (11) feeder dykes in the Dorsal Rift. Many of these dykes are shown in Figs. 3-9. Feeder dykes are more commonly exposed in Tenerife than in Iceland partly because of several large landslides and collapse calderas have occurred during the rift evolution, generating excellent scarps for detailed observations of dykes and their connections (or not) with eruptive rocks.

\section{Field observations}

With one exception (Fig. 4), all the observed feeder dykes in Iceland and Tenerife are subvertical (Figs. 3, 5-9) and trend parallel with the associated volcanic fissure and riftzone axis. This geometry is normally displayed independently of the eruption style and erupted volume. For example, the dykes in Fig. $3 \mathrm{~b}$ and $\mathrm{c}$ are connected to spatter cones of different sizes and the dyke in Fig. 3a is connected to small chimneys; however, they are all subvertical and sheet-like. These observations are entirely in agreement with theoretical considerations. As a rule, the maximum principal compres- sive stress is vertical at and close to the surface of a flat active rift zone, and so must be the dykes that reach its surface (e.g., Gudmundsson, 2002). This rule, however, does not apply to rift zones with great topographic highs, where the maximum principal stress may be inclined (perpendicular to a sloping surface), or when dipping (inclined) discontinuities such as contacts and faults are used by the dykes as channels to the surface. The one exception to the generally observed subvertical feeder dykes occurs where a feeder uses an inclined contact (Fig. 4). In this case the magma became transported, and the sheet propagated, sub-horizontally along the contact between two layers of pyroclastic rocks until close to the surface where the sheet became a sub-vertical dyke again and thus perpendicular to the palaeo-surface of the rift zone.

The feeder-dyke thickness is approximately constant along most of the dyke exposures (Figs. 3, 4). However, below spatter and cinder cones the thickness of the uppermost part of the feeder increases towards the vent (the palaeosurface). This is seen clearly in Fig. 3b and 3c. The increase in thickness is rapid in the dyke in Fig. 3b but gradual in the dyke in Fig. 3c, where the thickness increases from $4.5 \mathrm{~m}$ at about $100 \mathrm{~m}$ below the surface (close to the river at the bottom of the canyon) to $13 \mathrm{~m}$ at the surface (Gudmundsson et al., 2008).

We propose that the commonly observed thickness increase of feeder dykes on approaching the surface is partly because of magma-erosion effects, but mainly because of the free-surface effects. Erosion of the dyke walls may certainly occur (Bruce and Huppert, 1989), and is most likely to occur where feeders dissect scoria, sediments, and other unconsolidated materials. Nevertheless, it is rare to find many xenoliths in dykes, non-feeders as well as feeders. We have studied tens of thousands of dykes; very few contain abundant xenoliths that could be related to erosion of the dyke walls, suggesting that there is normally little wall erosion by the flowing magma. For some dykes, the lack of magma-related erosion of the dyke walls may be partly related the chilled selvage, the glassy margin, that develops at the contact between the dyke and the host rock. Most of the feeder dykes in the present study, however, have poorly developed chilled selvage. In contrast to comparatively small wall-erosion effects on feeder-dyke thicknesses, the free-surface effect on feeder-dyke thicknesses is common. It follows from the fact that the opening or aperture of an extension fracture is normally greatest at the free surface because there the elastic constraints on the opening-displacement are partly removed (Gray, 1992; Gudmundsson et al., 2008). The same results as to the commonly observed widening of feeder-dykes towards the surface have been obtained in other studies (e.g., Geshi et al., 2010).

Rarely, the dyke feeding a lava flow may decrease in thickness upwards towards the contact with the lava (Fig. 5). This geometric change is presumably because the overpressure (driving pressure) of the magma was declining rapidly towards the surface, or because the surface layer through which 

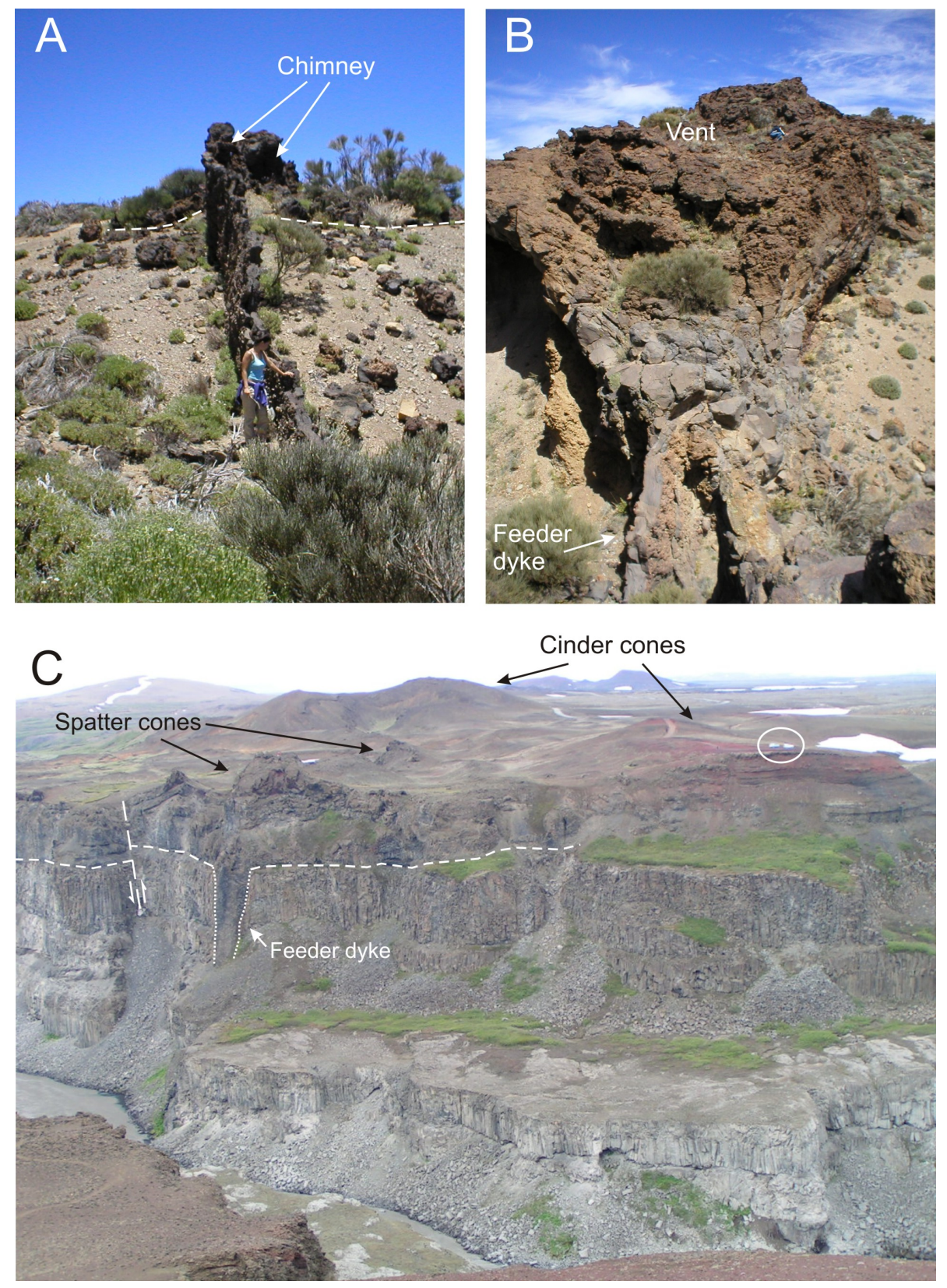

Fig. 3. Examples of subvertical sheet-like feeder dykes: (A) the Colmenas feeder dyke (Tenerife) connected to chimneys; (B) the Colmenas feeder dyke connected to a spatter cone; and (C) the Raudholar feeder dyke (Iceland) connected to a spatter cone. Observe the normal fault reactivated as a reverse fault by the dyke intrusion (Gudmundsson et al., 2008). See text for explanation. Dash lines indicate the palaeo-surface prior to the eruption. See persons for scale in (A) and (B); and cars inside the white circle for (C).

the dyke had to propagate was very stiff, that is, with a high Young's modulus (Geshi et al., 2010, 2012). In this case, the lower layer through which the dyke dissects is a soft pyroclastic layer (where the dyke is comparatively thick) whereas the surface layer on top of the pyroclastic layer is a stiff, basaltic lava flow (where the dyke becomes thinner).

These observations are supported by studies of dykes elsewhere. For example, Keating et al. (2008) report thickness changes in feeder dykes, from the depth of about $250 \mathrm{~m}$ be- low the surface, which, again, show that the dykes generally become thicker towards the surface. In their interpretation, the dyke thickness increases from $4-12 \mathrm{~m}$ in the depth range of $100-250 \mathrm{~m}$ to as much as $30 \mathrm{~m}$ at depths of about $50 \mathrm{~m}$. Also, studies in the walls of the AD 2000 caldera collapse in Miyakejima Volcano in Japan show that feeder dykes normally become thicker towards the palaeosurface (Geshi et al., 2010, 2012). The results, however, indicate that the dyke thicknesses depend much on the mechanical properties of the 


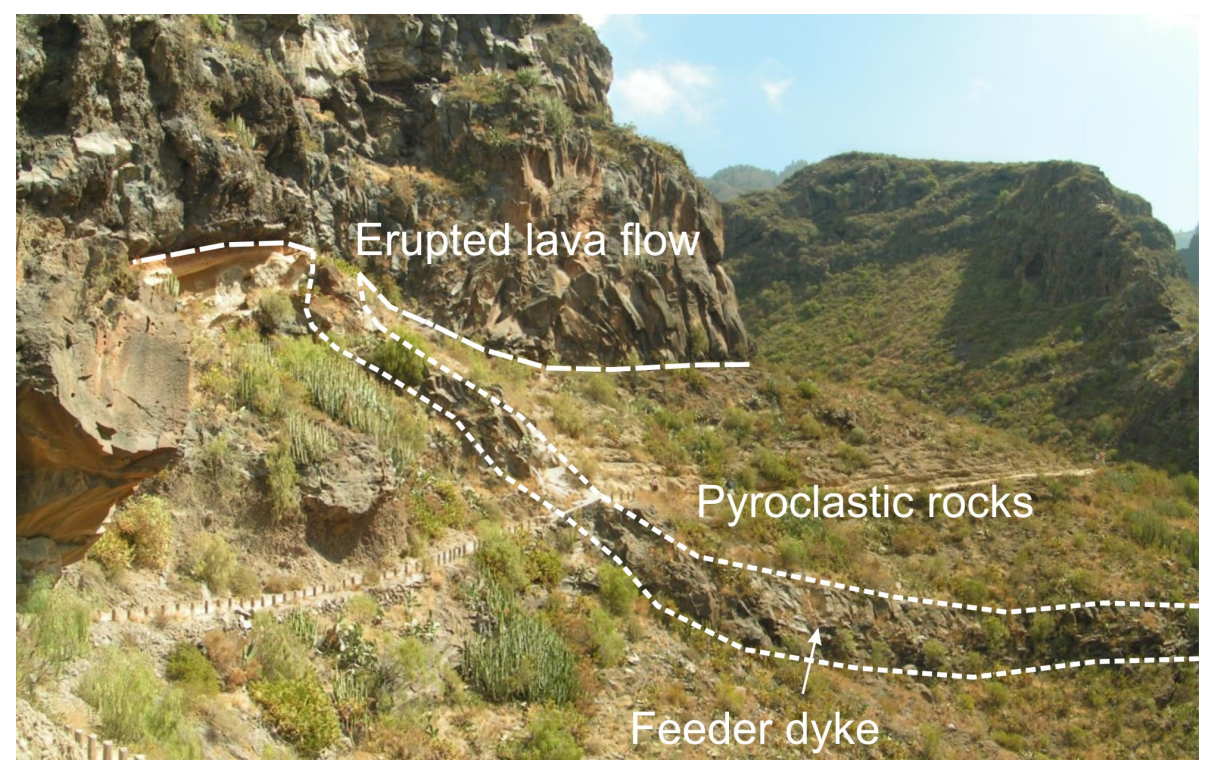

Fig. 4. Example of an inclined feeder dyke: the Infierno feeder dyke (Tenerife). As the dyke approached the surface it met a weak contact between two pyroclastic deposits and propagated into the contact - the contact being parallel with the stratification. However, just under the palaeo-surface the dyke turns and becomes perpendicular to the erupted lava flow.

layers that the dykes dissect on their paths to the surface. More specifically, the dykes tend to be comparatively thick where they dissect soft, pyroclastic layers but thinner where they dissect stiff lava flows.

All feeder dykes reported here (except the dyke in Fig. 4) are sub-vertical. Yet their margins are irregular in shape and many show fingers and apophyses (Figs. 5, 6). The apophyses are more common where the host rock is soft (mainly pyroclastics; Figs. 5 and 6). One remarkable dyke dissects the pyroclastic fallout deposits formed during eruption to which it was the feeder (Fig. 6b). This dyke shows a sort of pinchand-swell structure (a ball-chained structure). In this case, there is no relationship between the changes in thickness and the host-rock properties which are essentially uniform.

Chilled margins are mostly poorly developed and thin along the feeders and only occasionally glassy (obsidian). Where a feeder dyke intrudes a cinder cone, the lapilli deposits in the vicinity of the dyke are reddish and, closer to the dyke, become welded and stuck to the chilled margin (Fig. 6b). Parallel to the chilled margins in the dyke centre, an elongated hollow is sometimes observed (Fig. 7a). The elongated hollow or cavity is commonly confined to the uppermost 2-3 $\mathrm{m}$ of the dyke, that is, just below the surface. The opening (aperture) of the hollow may be several tens of centimetres and is lined with solidified magma drops (Fig. 7b).

Vesicles are common in the deeper parts of the feeder dykes. For any particular feeder, vesicles tend to increase rapidly in size and number close to the surface and towards the central part of the dyke (Fig. 7c). They are distributed in bands parallel to the dyke margins, generally elongated (elliptical) in shape and with the major axis parallel with the chilled margins (Fig. 7c, d). Some vesicles, however, are drop or pear-shaped (Fig. 7e), suggesting a sub-vertical (upward) movement of gas bubbles relative to the surrounding magma. Vesicles have commonly been used to infer the flow direction of magma in dykes, the normal assumption being that the vesicles are elongated parallel with the flow direction (e.g., Rickwood, 1990). However, as for many strain indicators whose formation is not fully understood in terms of well-tested physical theories, a straightforward interpretation of the vesicle shape in terms of magma flow direction in dykes is open to doubt.

Every single feeder dyke is segmented (Fig. 8). The scale of the segmentation is different between Iceland and Tenerife, the segments being thicker (Fig. 8) and longer in Iceland (Gudmundsson, 1986, 2002). In addition, the offsets of the dyke segments are much greater for the Icelandic dykes, commonly many metres, than for the dykes in Tenerife. The generally larger offset of dykes in Iceland is partly attributable to their greater thicknesses. There is a crude relationship between the thickness of a dyke and its potential offset (Gudmundsson, 1986), so that, since the regional dykes in Iceland are much thicker than those in Tenerife, the dykeoffsets tend to be larger in Iceland. Both in Iceland and Tenerife, however, the offset dyke segments in the vertical sections are linked either through thin, igneous veins (Gudmundsson, 1986), or connected through narrow channels (Fig. 8a) formed by the lateral prolongation of individual fingers of the dyke segments. The thicknesses of the segments reach their maximum close to their centres and then decrease towards the tips or the connection channels (Fig. 8a). 


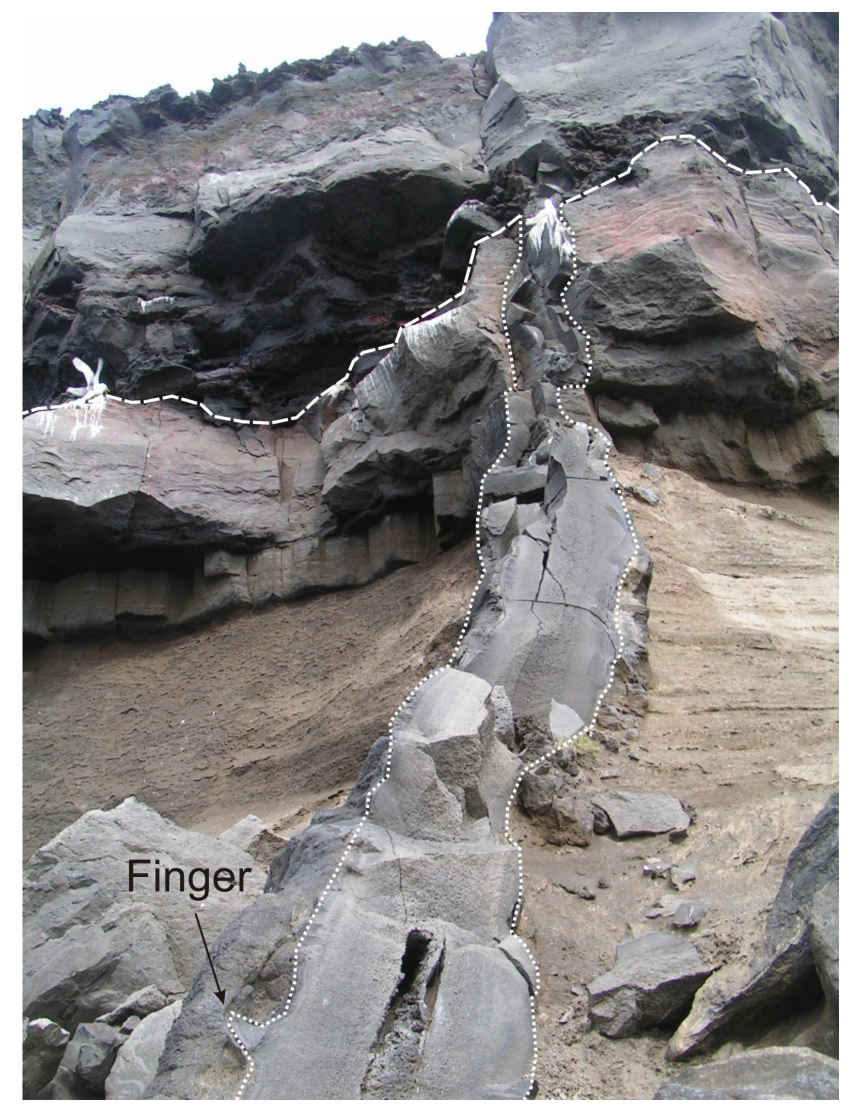

Fig. 5. The Reykjanes dyke (Iceland) feeding a lava flow. The dyke dissects soft pyroclastic layers and then, at the top, a stiff basaltic lava flow. The stiffening of the host rocks may be the cause of the decreasing of dyke thickness upwards towards the vent. The dashed line indicates the palaeo-surface.

Mechanical interactions between the propagating feeder dykes and existing faults have been also observed in two feeder dykes. The first example was previously reported by Gudmundsson et al. (2008) who, based on field observations and numerical models, suggest that the dyke intrusion of the Raudholar feeder dyke (see Fig. 2a for location) reactivated an existing normal fault, namely a boundary fault of a graben (Fig. 3c). The reactivation resulted in reverse slip on the normal fault closest to the dyke, probably when the overpressured feeder dyke approached and then reached the surface. The reverse slip on the fault accommodated part of the thickness increase of the feeder, from 4.5 to $13 \mathrm{~m}$, when it reached the surface.

Another example from Tenerife shows the interaction between the Colorada feeder dyke, from the Dorsal Rift (Fig. 2b), and a small normal fault (Fig. 9). The magma intruded up along the normal fault, reached the surface, and erupted forming a small lava flow. This feeder dyke has a trend approximately perpendicular to the main trend of the Dorsal Rift. However, this direction is not the main trend of the feeder dyke but is rather the trend of the fault that it fol- lows at this locality. This is supported by the fact that $25 \mathrm{~m}$ below the surface the dyke trend coincides with that of the Dorsal Rift and intersects the normal fault; part of the dyke magma flowed up along the fault plane through a pipe structure (Fig. 9). At the point of intersection between the dyke and the fault, a ball-shaped structure is observed (Fig. 9). The existence of the fault does not affect the main trend of the dyke. No evidence of fault reactivation was observed. Interactions between faults and feeder dykes have been observed in other volcanic areas and play a role in assessing volcanic hazards such as at Etna (e.g., Cappello et al., 2012).

\section{Feeder-dyke identification}

In eroded volcanic areas it is normally difficult to identify feeder dykes because the erupted deposits have been eroded or are not clearly related to the feeder. This study provides information to help to identify basaltic feeder dykes. Based on the present field observations, feeder dykes show several features that are also common with dykes in general. For example, feeder dykes are generally sheet-shaped subvertical structures with irregular margins. Also, feeder dykes are normally segmented (as are the associated volcanic fissures). Some features, however, are more specific to feeder dykes (as distinct from non-feeders) and can be used to identify feeders. These features include the following:

- Feeder dykes contain vesicles that increase in size and number close to the surface. The depth at which this increase becomes noticeable depends on composition of the dyke magma and other factors, but some such effects may be seen to depths as great as several hundred metres below the surface. This is supported by observations in Hawaii which indicate that significant degassing of basaltic feeder dykes may occur to a depth of several hundred metres (Greenland et al., 1988).

- Feeder dykes normally contain elongated (prolate ellipsoidal) cavities in their central, topmost parts, particularly close to (within 2-3 m of) the surface. Commonly, there are solidified magma drops on the cavity walls. These cavity structures have not been reported for nonfeeder dykes. While not all feeder dykes have such elongated cavities, where they do occur they help distinguish between feeders and non-feeders.

- Some feeder dykes inject oblique fingers into the planes of existing faults that cross the dyke paths, and may reactivate, that is, trigger slip on existing faults. While this applies to dykes in general, it is more likely to occur close to the surface where, for normal faults, the dip commonly becomes steeper and the normal stress on the fault plane thus smaller and easier for the magma to use the fault as a channel (Gudmundsson, 1986). 

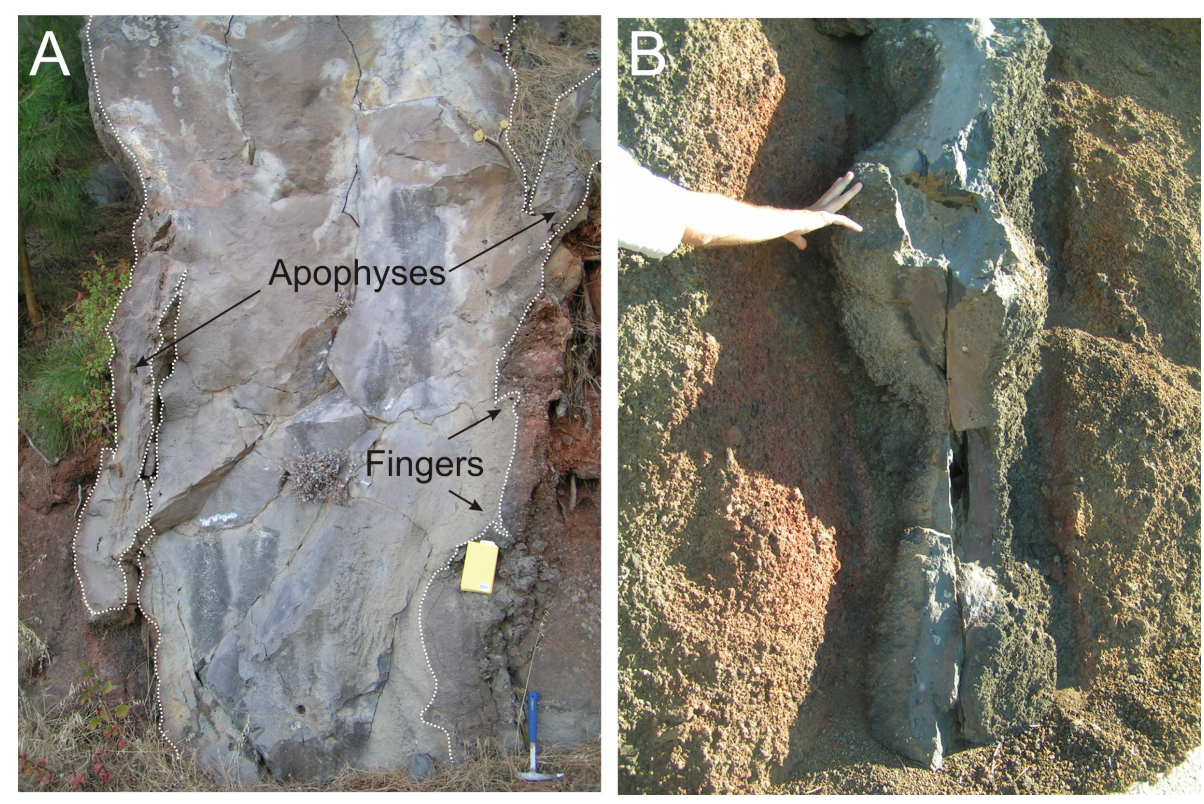

Fig. 6. Feeder dykes showing irregular margins: (A) the Chese feeder dyke (Tenerife) shows several apophyses and fingers. (B) The Negrita feeder dyke (Tenerife) displays a ball-and-chain structure in its more superficial part, when intruding pyroclastic deposits of the cinder cone formed during its eruption.

- Close to the surface most feeders increase their thickness which, at the surface, may be at least several times the dyke thickness at some tens or hundreds of metres below the surface (Fig. 3c; Gudmundsson et al., 2008; Keating et al., 2008; Geshi et al., 2010, 2012).

\section{From the conduit to the deposits}

The feeder-dyke rock represents the magma characteristics as they were at the end of the eruption. The field results indicate that the magma was not completely degassed by the end of the eruption, since vesicles are common. Moreover, enderuption magma withdrawal is inferred from the commonly observed magma drops covering the central hollow parts of several of the feeder dykes. The magma could have flowed down the conduit at the end of the eruption at that particular locality, either because of general magma-pressure decrease in the conduit or because the eruption (and the magma) migrated to another vent along the fissure.

Close to the vent, the conduit increases in thickness. The thickness increment seems to be related of the volume of the erupted deposits, being greater where a spatter cone is well developed. As a field example supporting this suggestion, consider Fig. 3. Figure 3a shows a location under a vent that did not erupt volcanic material, but rather gas, so it can be considered as the initial stage, when the dyke was reaching the surface. As the dyke reaches the surface and starts to form a spatter cone, as seen in Fig. 3b, the vent expands; finally, if the eruption goes on over enough time, the magma has time to widen the conduit, as in Fig. 3c, perhaps partly through some erosion and partly through the free-surface effects on the fracture opening (Gudmundsson et al., 2008).

\section{Feeder-dyke propagation}

Feeder dykes propagate primarily in the same way as nonfeeder dykes, that is, as pure opening (mode I) fractures driven by magmatic overpressure (Gudmundsson, 2002). The dyke-fracture is perpendicular to the minimum compressive (maximum tensile) principal stress $\sigma_{3}$. This stress is normally perpendicular to the rift-zone axis, so that the dykes tend to be parallel to that axis, as is observed in this study. The propagation is commonly through crustal layers that are stresshomogenised, that is, behave as essentially a single mechanical layer at the time of feeder-dyke emplacement. By contrast, when the crustal layers are not stress-homogenised, they may develop local stresses that are unfavourable for dyke propagation, or have contacts that are similarly unfavourable, in which case the dykes would become arrested and not reach the surface to become feeders (Gudmundsson, 2012a). However, the geometries of the feeder and the nonfeeder dykes are commonly different, particularly close to the surface, as indicated by the results presented here and in other works (Keating et al., 2008; Geshi et al., 2010, 2012).

Field observations and model results suggest that a feederdyke injection is strongly affected by local stress fields associated with changes in the mechanical properties of the host rocks and the properties of existing structures, such as contacts and faults. Local stresses and existing structures may contribute to dyke segmentation and to parts of the dyke 

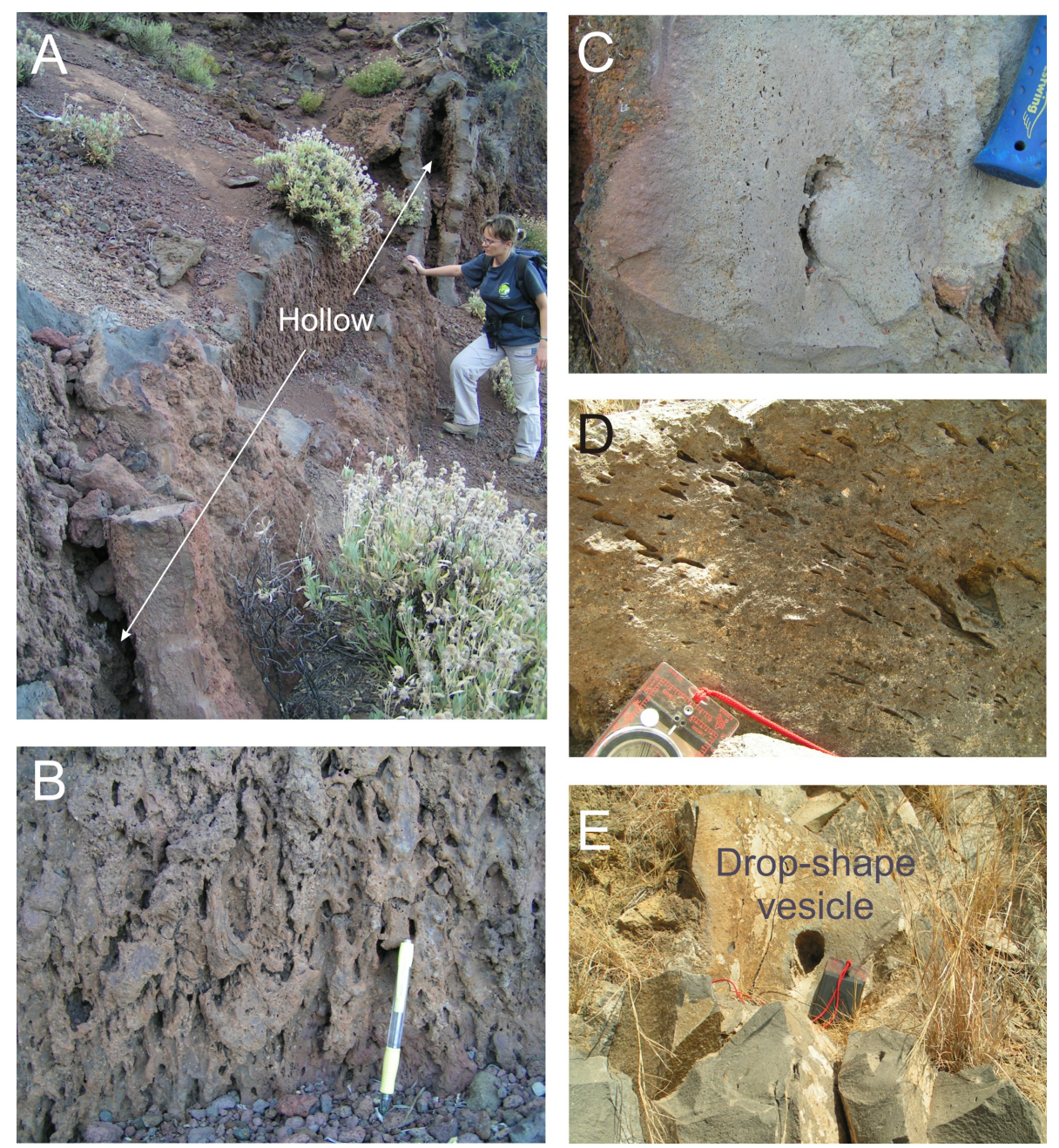

Fig. 7. (A) Central elongated hollow of the Colorada feeder dyke (Tenerife). (B) Details of the magma drops at the central hollow. (C) Vesicles in bands and increasing in size and number from the chilled margins to the dyke centre. (D) Elongated vesicles. (E) A drop or pear-shaped vesicle.

being inclined rather than sub-vertical. The segmentation is also related to the propagation process itself (Gudmundsson, 1986), since the dyke-propagation front is formed by fingers that propagate vertically and laterally and tend to coalesce. Occasionally, the dyke fingers or segments combine in a manner indicated by Fig. 8a. Independently of the dyke dip at depth, when reaching the surface, the dyke always becomes perpendicular to it because it follows the stress trajectories that must be either parallel or perpendicular to a free surface (Fig. 4).

There are two additional factors that affect dyke propagation, particularly close to and at the surface. One is the topography of the volcanic area of dyke emplacement, the other is existing structures in the path of the dyke. It is well known that the stress fields in large volcanic edifices, particularly close to the surface, are affected by the topography of the edifice. The general topography may thus affect the dykepropagation path (e.g., Acocella and Neri, 2009; Acocella et al., 2009). In addition, abrupt topographic changes, such as lateral or sector collapses, may affect the dyke-propagation path (Galindo, 2005; Neri et al., 2008). The topographic effect is thus partly due to the modification of the local stress field, and partly because of vertical to steeply dipping free surfaces, such as the walls of lateral and vertical collapse structures. All the feeder dykes from Iceland considered here (Fig. 2a) are from flat rift zones, except the feeder of the Hekla 1991 eruption (Sect. 9). The feeder dykes in Tenerife are located within the three rift zones of the island (Fig. 2b). Topography clearly plays a role in the mechanism of volcano spreading that operates on Tenerife. We have not, however, found evidence of abrupt changes in feeder-dyke trends that can be attributed to topographical effects. But there is abundant evidence of the effects of the free surface of the rift zones and of contacts and other discontinuities on the dykepropagation paths (Fig. 4). 

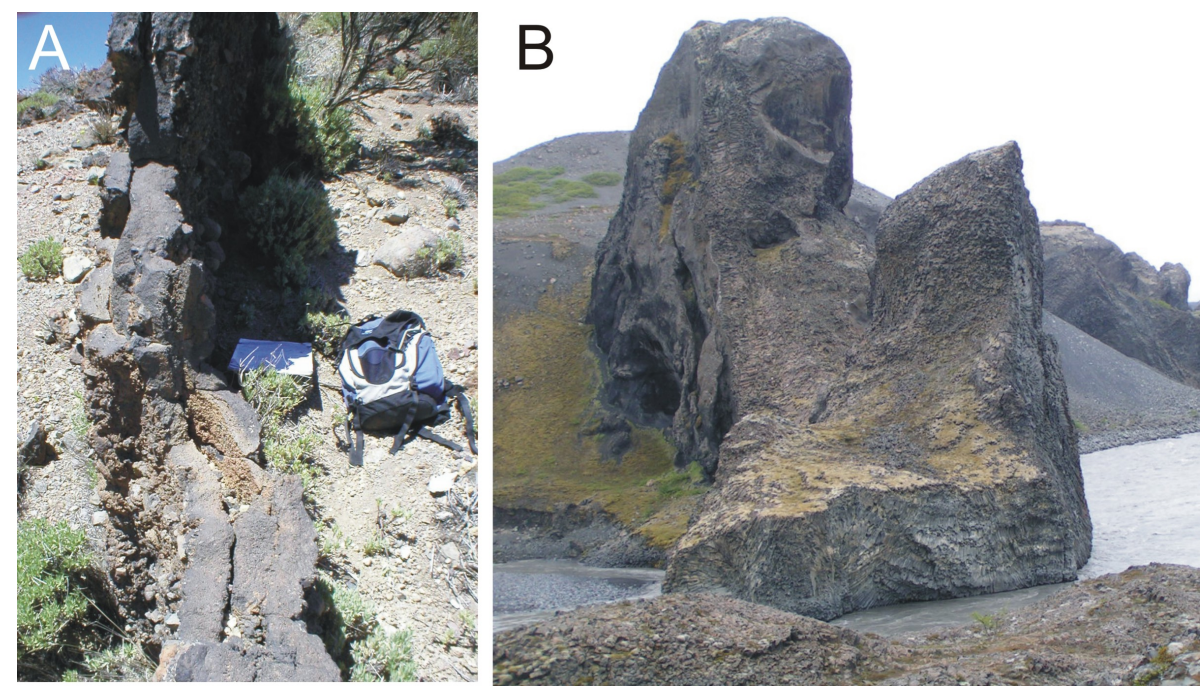

Fig. 8. Segmented feeder dykes. (A) The Colmenas feeder dyke (Tenerife) is composed of several segments some of which have coalesced through narrow channels. The segment main trend changes when approaching the nearby segment. (B) The Hljodaklettar feeder dyke (Iceland) is much thicker (approximately $25 \mathrm{~m}$ ) than the Colmenas dyke and the segments are longer.

The second factor, existing structures, may have a strong influence on the location of additional vents around the main eruptive fissure. However, these structures do not normally affect the main propagation of the feeder dyke, in particular when the structures, such as faults, that are comparatively small (Figs. 3c and 9). A detailed study of feeder dykes and fissure eruptions cutting faults will be needed to obtain a clearer picture of the exact relationship between dykes and faults. The present results indicate, however, that in analysis of feeder dykes the possibility must be considered that a part of a feeder is using a fault as a channel (Fig. 9), in which case the attitude of that dyke part would not be representative of the stress field of the area. In particular, a dyke part occupying a fault plane is not in a principal stress plane and thus cannot be used to indicate the orientation of the principal stresses at its time of emplacement.

Dykes induce stresses and displacements at and close to the Earth's surface when approaching it (Pollard and Holzhausen, 1979; Pollard et al., 1983; Rubin and Pollard, 1988; Bonafede and Olivieri, 1995; Rubin, 1995; Bonafede and Danesi, 1997; Acocella and Neri, 2003; Gudmundsson, 2003; Gudmundsson et al., 2008). Hence, surface deformation takes place before the eruption as well as at the moment the feeder intersects the Earth's surface. The probability of a volcanic unrest period resulting in an eruption, that is, in a feeder-dyke formation, is easier to assess if we have a better knowledge of how and in which way feeder dykes and faults and other discontinuities interact mechanically.

\section{Volumetric flow rate through a feeder dyke}

When a feeder-dyke reaches the surface to form a volcanic fissure, the volumetric flow or effusion rate of the fissure can be calculated. The calculation is based on the NavierStokes equation for laminar flow between parallel plates (e.g., Lamb, 1932; Milne-Thompson, 1996). The volumetric flow rate, $Q$, in $\mathrm{m}^{3} \mathrm{~s}^{-1}$ is obtained from the equation:

$Q=\frac{\Delta u^{3} W}{12 \mu_{\mathrm{m}}}\left[\left(\rho_{\mathrm{r}}-\rho_{\mathrm{m}}\right) g \sin \alpha-\frac{\partial p_{\mathrm{e}}}{\partial L}\right]$.

Here $\Delta u$ is the opening or aperture of the volcanic fissure or feeder dyke, $W$ is the length or strike dimension of the volcanic fissure or feeder-dyke as measured at the surface, $\mu_{\mathrm{m}}$ is the dynamic or absolute viscosity of the magma in Pa s, $\rho_{\mathrm{m}}$ is the density of the magma in $\mathrm{kg} \mathrm{m}^{-3}$ (assumed constant), $\rho_{\mathrm{r}}$ is the average density of the crustal segment (which includes the volcano) through which the feeder dyke propagates to the surface, $g$ is the acceleration due to gravity in $\mathrm{m} \mathrm{s}^{-2}, \alpha$ is the dip of the feeder dyke in degrees, and $\partial p_{\mathrm{e}} / \partial L$ is the vertical magmatic excess-pressure gradient in the direction of the magma flow, that is, in the direction of the dip dimension of the dyke $L$ in metres.

When discussing the flow of magma through a feeder dyke that originates in a magma chamber, there are two pressure concepts that need to be considered. One has already been referred to in connection with the pressure gradient in Eq. (1), namely the excess pressure. Here, excess pressure $\left(p_{\mathrm{e}}\right)$ is the magma pressure in excess of the lithostatic pressure (or overburden pressure) in the magma chamber at the time of its rupture and feeder-dyke initiation. At the time of magmachamber ruptured, the excess pressure in the chamber is normally equal to the tensile strength of the host rock, generally 

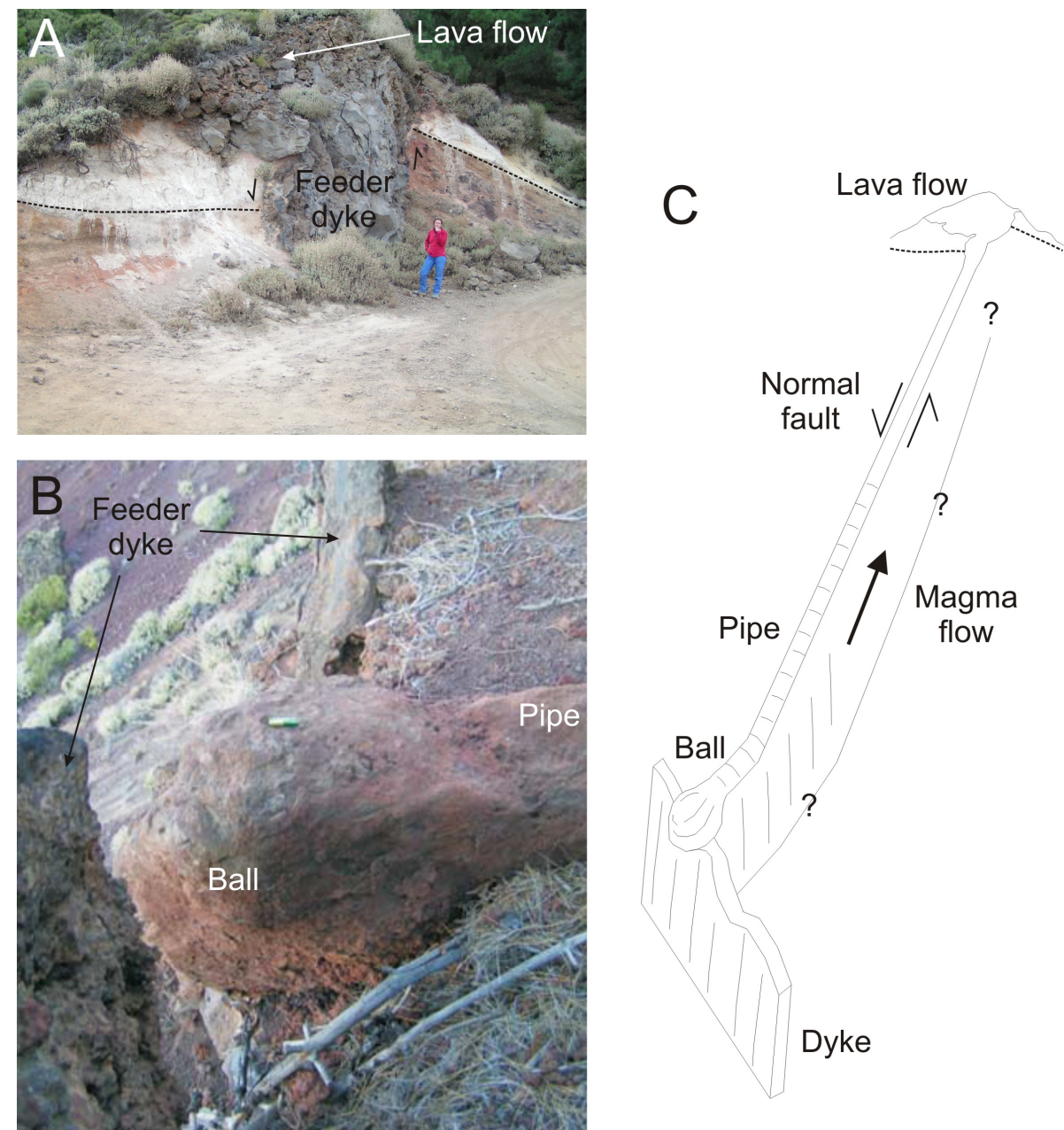

Fig. 9. (A) Outcrop of a shallow normal fault intruded by the Colorada feeder dyke (Tenerife), where the magma transported by the dyke extrudes and forms a small lava flow. No clear indicators have been found to suggest the reactivation of the fault due to the dyke intrusion. (B) Ball-shaped structure formed at the place where the feeder dyke cuts the fault. From the ball, a pipe structure propagates up to the fault. The main feeder-dyke trend is perpendicular to the fault plane (pipe). (C) Schematic illustration of the likely dyke propagation along the fault and to the surface to form the small lava flow.

in the range of 0.5-9 MPa, and most commonly about $3 \mathrm{MPa}$ (Haimson and Rummel, 1982; Schultz, 1995).

The second concept is overpressure $\left(p_{0}\right)$, which is also commonly referred to as driving pressure and net pressure. It is the pressure that drives the propagation of the feeder dyke (and other sheet-like intrusions). The magnitude of the overpressure derives from the combined effects of the initial excess pressure in the source chamber and the magma buoyancy. The buoyancy is because of the difference between the density of the magma in the feeder dyke and the density of its host rock, as indicated in the first term $\left(\rho_{\mathrm{r}}-\rho_{\mathrm{m}}\right) g$ in the parenthesis in Eq. (1). More specifically, overpressure is the total pressure minus the normal stress which acted on the potential feeder-dyke path before magma emplacement. For any extension fracture such as a dyke, the normal stress is the minimum principal compressive stress $\sigma_{3}$. From Eq. (1) it follows that the excess pressure decreases up the feeder dyke, whereas the buoyancy term increases so long as the average density of the host-rock through which the feeder dyke propagates is greater than the density of its magma. The overpressure may reach several tens of mega-pascals at some point along the dyke path, despite the fact that the excess pressure in the source magma chamber is normally equal to the rock tensile strength and thus only several mega-pascals.

When applying Eq. (1) to volumetric flow up through a feeder dyke, it should be noted that the aperture $\Delta u$, here assumed constant, depends on the magmatic overpressure. Here the overpressure $\left(p_{0}\right)$ derives from the term in the brackets, and is partly due to the excess pressure $p_{\mathrm{e}}$ in the source magma chamber of the dyke, and partly on the buoyancy term $\left(\rho_{\mathrm{r}}-\rho_{\mathrm{m}}\right) g$ as defined above (note that the term is multiplied by the height or length $L$ to get the proper 
units). The aperture is thus known to vary with overpressure, and can be modelled in various ways (e.g., Gudmundsson, 1986; Gray, 1992; Kusumoto et al., 2012). Currently, however, there are no available analytical models that allow the coupled changes in overpressure and aperture to be directly related to changes in volumetric flow rates during volcanic eruptions. Thus, in the analysis below, we explore changes in the feeder-dyke aperture independently of the changes in the associated magma overpressure.

\section{Pressure changes in the source magma chamber}

During a dyke-fed eruption, there is a certain volume of magma, $V$, that is transported to the surface from the source magma chamber before the eruption comes to an end. While some magma chambers, particularly small sill-like chambers, may be totally molten, most chambers are likely to be only partially molten and behave as poroelastic bodies. For a poroelastic magma chamber, the total volume of magma transported by a feeder dyke to the surface (and including the volume of the feeder itself) during an eruption may be estimated as follows (e.g., Gudmundsson, 2012a):

$V=f p_{\mathrm{e}}\left(\beta_{\mathrm{p}}+\beta_{\mathrm{m}}\right) V_{\mathrm{c}}$.

Here, $f$ is the porosity of the chamber, or its magma fraction (no units), $p_{\mathrm{e}}$ is the magma excess pressure in the chamber before rupture and feeder-dyke formation (in pascals), $\beta_{\mathrm{m}}$ is the magma compressibility and $\beta_{\mathrm{p}}$ the pore compressibility of the magma chamber (both with units of $\mathrm{Pa}^{-1}$ ), whereas $V_{\mathrm{c}}$ is the total volume of the chamber.

Equation (2) is well known from poroelasticity (cf. Bear, 1972; Wang, 2000) and hydrogeology (Deming, 2002). For a totally fluid magma chamber, the factor $f=1$, and many have used that version of the equation (e.g., Machado, 1974; Blake, 1981). Generally, the flow out of the magma chamber through the feeder-dyke stops, and the eruption comes to an end, when the excess pressure is no longer able to keep the dyke-fracture open at its contact with the chamber (Fig. 10), that is, when $p_{\mathrm{e}} \rightarrow 0$.

For non-feeder dykes, that is, dykes that end vertically within the volcano and do not reach the surface, the dykefracture does not need to close when the dyke stops its vertical propagation. Rather, the dyke propagation simply stops when the dyke becomes arrested and subsequently the dyke solidifies and gradually cools down to the temperature of the host rock. Non-feeder dykes, particularly when composed of high-viscosity felsic magmas, that cut the roofs of fossil magma chambers may thus be seen as connected to the source magma, that is, the present felsic pluton (Gudmundsson, 2012b). But for feeder dykes, particularly low-viscosity basaltic dykes, the contact with the magma chamber would normally effectively close at the end of the eruption (Fig. 10).

Consider now how the volumetric flow rate through a feeder dyke such as in Fig. 3a decreases during the eruption.

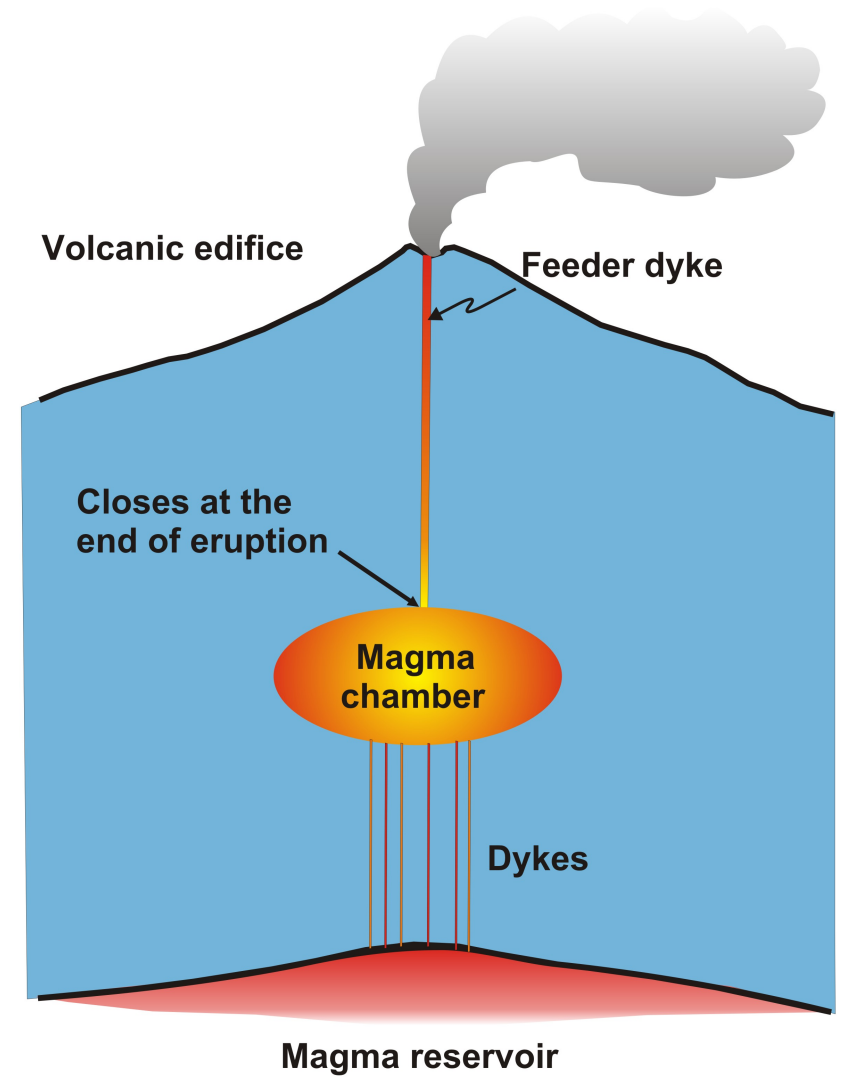

Fig. 10. Schematic illustration of a feeder dyke extending from a crustal magma chamber to the surface of a volcanic edifice. The crustal magma chamber, in turn, is supplied with magma from a deeper magma reservoir, in the lower crust or at the top of the mantle. For a basaltic feeder dyke, the bottom of the dyke closes when the excess pressure in the chamber is no longer able to hold the dyke-fracture open at its junction with the chamber. When this happens, magma flow up the feeder dyke ceases and the eruption comes to an end.

All the feeder dykes discussed in this paper are basaltic (or of basaltic andesite), so we consider only basaltic (and basaltic andesite) eruptions here, but the results can be generalised to other magma compositions (where, however, gas exsolution, the viscosity of the magma, and other factors may play a more important role). To simplify the problem, we present the volumetric flow rate over a given time $t$ during the eruption by the average value $Q t$. Also, we assume the host rock and magma densities to be equal, in which case we have, in Eq. (1), $\left(\rho_{\mathrm{r}}-\rho_{\mathrm{m}}\right) g L=0$. Consequently, the magma transport up through the feeder dyke is solely due to the excesspressure gradient, $\partial p_{\mathrm{e}} / \partial L$ in Eq. (1).

When magma starts to flow up the feeder dyke, and eventually to the surface (Fig. 10), the excess pressure in the source chamber must normally decrease. The only exceptions would be if (i) gas exsolution and related processes maintain the excess pressure and/or (ii) if new magma is injected into the chamber from its source reservoir (Fig. 10) at 


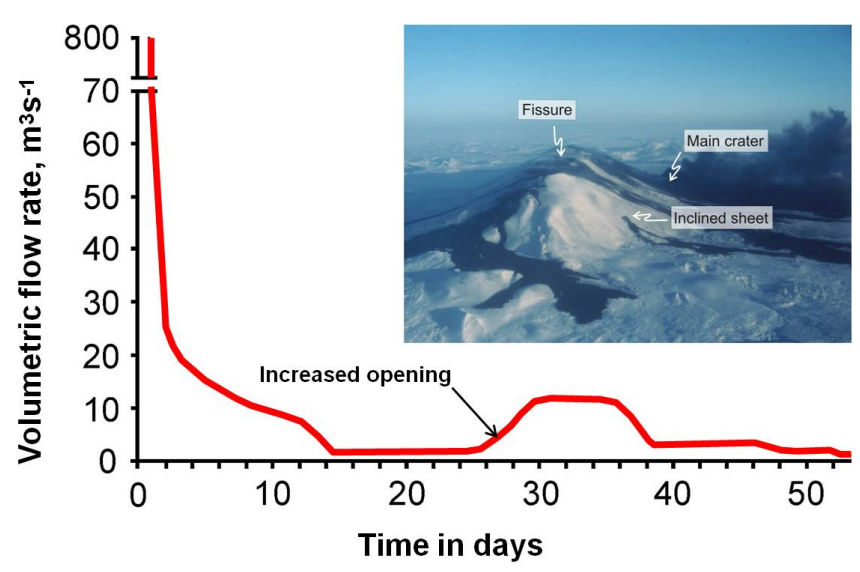

Fig. 11. Variation in the volumetric flow or effusion rate in the 1991 Hekla eruption in Iceland as a function of time. The abrupt increase in the volumetric flow rate is here thought to be related to a small increase in the opening (aperture) of the feeder dyke. On the inset is a photograph of the Hekla Volcano early in the eruption (cf. Gudmundsson et al., 1992).

the same volumetric flow rate as magma leaves the chamber through the feeder dyke. The first factor is not likely to be of great importance in the basaltic eruptions discussed here, but may be so in explosive eruptions, particularly collapsecaldera eruptions. Experience from basaltic eruptions worldwide indicates that the inflow of magma is normally at a much lower volumetric rate than the outflow through the feeder dyke (e.g., Stasiuk et al., 1993; Woods and Huppert, 2003).

The main exceptions to this rule may be volcanoes such as Stromboli (Italy) and Sakura-Jima (Japan) and active lava lakes such as in Kilauea (Hawaii), Nyiragongo and Erta Ale (Africa), and Mount Erebus (Antarctica), where there is a quasi-continuous eruptive activity over long periods of time (Simkin and Siebert, 2000; Frank, 2003; Rosi et al., 2003; Siebert et al., 2010). In these volcanoes the rate of magma injection into the chamber, or replenishment, may be very similar to the feeder-dyke effusion rate. However, volcanoes with such a quasi-continuous activity are few and maintain that activity for short periods of time (with the possible exception of Stromboli) in comparison with their overall lifetimes. For estimating the volumetric flow rates during most basaltic eruptions, therefore, the new magma received by the chamber, that is, the replenishment, may be ignored.

On these assumptions, and for a basaltic (and basaltic andesite) eruption, the excess pressure $p_{\mathrm{c}}$ in the source chamber of the feeder dyke at any instant may be given by:

$p_{\mathrm{c}}=p_{\mathrm{e}}-\psi \int_{0}^{t} Q \mathrm{~d} t$.

Here, $p_{\mathrm{e}}$ is the excess pressure at the time of magmachamber rupture and feeder-dyke emplacement (and eruption initiation), that is, at $t=0$, and $Q$ is the volumetric flow or effusion rate. The factor $\psi$ has the units of $\mathrm{Pa} \mathrm{m}^{-3}$ and is the reciprocal of the right-hand side of Eq. (1), thus:

$\psi=\left[f\left(\beta_{\mathrm{p}}+\beta_{\mathrm{m}}\right) V_{\mathrm{c}}\right]^{-1}=\frac{p_{\mathrm{e}}}{V}$.

The flow rate $Q$ up through the feeder dyke as a function of time is given by (Machado, 1974):

$Q=Q_{\mathrm{e}}-A \int_{0}^{t} Q \mathrm{~d} t$.

Here, $Q_{\mathrm{e}}$ is the initial flow rate and $A$ is a constant that is related to the excess pressure, compressibility and volume of the magma chamber as well as to the dimensions of the feeder dyke.

It can be shown that the solution to Eq. (5) (Machado, 1974; cf. Wadge, 1981) has the form:

$Q=Q_{0} e^{-A t}$.

Equation (6) shows that the volumetric flow rate up through the feeder dyke is a negative exponential function of time since the beginning of the eruption or, strictly, the rupture of the magma chamber and feeder-dyke initiation. A roughly exponential decrease in the volumetric flow or effusion rates is common during eruptions (Machado, 1974; Wadge, 1981; Stasiuk et al., 1993; Thordarson and Self, 1993; Thordarson and Larsen, 2007; Neri et al., 2011). One such example (with irregularities, however) is provided in Fig. 11.

Using similar arguments, it can be shown, based on the above assumptions and by analogy with Eq. (6), that the excess-pressure $p_{\mathrm{c}}$ in the magma chamber during the eruption is also a negative exponential function of time and given by (cf. Woods and Huppert, 2003):

$p_{\mathrm{c}}=p_{\mathrm{e}} e^{-\left(\frac{Q t}{V}\right)}$.

Here $V$ is the volume of the eruptive materials plus the volume of the feeder dyke, as defined in Eq. (1), $Q$ is the volumetric flow rate up the feeder, so that $Q t$ is the volume during the time interval $t$. Since the units of $Q t$ are $\mathrm{m}^{3}$, it follows that the exponent has the units of $\mathrm{m}^{3} \mathrm{~m}^{-3}$ and is thus dimensionless. A roughly exponential decrease in excess pressure in the source magma chamber during a basaltic eruption can therefore be expected until the pressure becomes too low to keep the feeder dyke open at its contact with the chamber, whereby the eruption comes to an end.

\section{Changes in the volumetric flow rate}

Equations (5) and (6) show that the volumetric flow rate or effusion rate depends on the variation in the excess pressure 
in the chamber, which itself is a negative exponential function of time (Eq. 7). There are, however, other factors that contribute to the volumetric flow rate, including the length of the feeder-dyke/volcanic fissure, the dynamic viscosity of the magma, the density difference between the magma and the host rock, the dip of the feeder-dyke, and the opening/aperture of the feeder-dyke/volcanic fissure at the surface (Eq. 1). For a feeder issuing magma of a given composition and viscosity, any abrupt changes in the volumetric flow rate during an eruption may be related to overpressure changes, but are most likely to be related to changes in the feeder-dyke length and, in particular, to its opening or aperture. This follows because, according to Eq. (1), the volumetric flow rate for laminar flow depends on the aperture in the third power (referred to as the cubic law), which means that small changes in the size of the aperture may have large effects on the volumetric flow rate. Following an earthquake, or other tectonic movements, the aperture and length of the active part of a volcanic fissure/feeder dyke may suddenly change during the eruption. And even if the change is small, the cubic law implies that the change in volumetric flow rate may be very noticeable - with obvious implications for hazards. Thus, while many eruptions show smoothly declining effusive rates (Machado, 1974; Wadge, 1981; Stasiuk et al., 1993; Thordarson and Self, 1993; Thordarson and Larsen, 2007; Neri et al., 2011), other eruptions show abrupt changes in the rates at certain times during the eruption.

All the feeder dykes described and explored in the present paper were injected hundreds or thousands of years ago. Thus, we do not have any information about the volumetric flow rates, or variations in these, during the associated eruptions. We therefore decided to use the feeder to the 1991 Hekla eruption in Iceland, where the length of the dyke (the volcanic fissure) is well known and where the volumetric flow rate is also well documented (Gudmundsson et al., 1992), and the eruptive volume similar to that of a typical small basaltic eruption $\left(0.25 \mathrm{~km}^{3}\right)$ in Iceland. The eruptive material was basaltic andesite so that the dyke is similar in composition to the feeder dykes described in the present paper. In addition, the 1991 Hekla eruption is a good example of changes in volumetric flow rates during an eruption (Fig. 11).

We shall now make rough estimates of the feeder-dyke dimensions for three stages of the eruption: the beginning phase, the middle phase (which is also similar to the end phase), and the following temporary abrupt increase in the flow rate before the end phase. The depth of the source magma chamber supplying magma to Hekla's basaltic eruptions is generally thought to be about $10 \mathrm{~km}$ (Gudmundsson et al., 1992), and the corresponding crustal segment has an average density of about $2800 \mathrm{~kg} \mathrm{~m}^{-3}$ (Gudmundsson, 2002). For a basaltic andesite magma we may take the density as $2650 \mathrm{~kg} \mathrm{~m}^{-3}$ and the viscosity as $100 \mathrm{~Pa}$ s (Murase and McBirney, 1973; Kilburn, 2000; Spera, 2000). Since the excess pressure in the chamber before rupture and feederdyke initiation is roughly equal to the in-situ tensile strength of the roof of the chamber, the excess pressure may be taken as $3 \mathrm{MPa}$ (Haimson and Rummel, 1982; Schultz, 1995). All these parameters can vary, but the likely variation does not much affect the main points of interest here.

During the initial phase of the 1991 Hekla eruption, the volumetric flow rate reached at least $800 \mathrm{~m}^{3} \mathrm{~s}^{-1}$, and may for the first few hours have reached about $2000 \mathrm{~m}^{3} \mathrm{~s}^{-1}$. During this time the volcanic fissure was about $3 \mathrm{~km}$ long (Fig. 11). Using Eq. (1) for a vertical feeder dyke (the $\operatorname{dip} \alpha=90^{\circ}$ ) and the above values for the physical parameters, we obtain the opening or aperture of the feeder dyke at the surface, that is, the aperture of the volcanic fissure, as about $0.56 \mathrm{~m}$. This applies to the effusion rate of $800 \mathrm{~m}^{3} \mathrm{~s}^{-1}$. In the first hours when the effusion rate may have reached $2000 \mathrm{~m}^{3} \mathrm{~s}^{-1}$, the fissure aperture (for the same fissure length) would have been about $0.77 \mathrm{~m}$. Both these values are very similar to common thicknesses of dykes and inclined sheets in fossil central volcanoes in Iceland (Gudmundsson, 2002, 2003).

A few days after the initial phase, the effusion became confined to a short fissure segment that was active for about 50 days and generated the main crater cone (Fig. 11). This segment was only several hundred metres long (similar to many volcanic fissures in Tenerife and many short fissures in Iceland), and we take it here as approximately $200 \mathrm{~m}$ long for the present calculations. Whether it was $100 \mathrm{~m}$ or $300 \mathrm{~m}$ would not greatly affect the results which depend much more on the fissure aperture. After about 14 days the effusion rate fell to $1-2 \mathrm{~m}^{3} \mathrm{~s}^{-1}$ and stayed at that low level for 12 days until is increased abruptly to $12 \mathrm{~m}^{3} \mathrm{~s}^{-1}$ (Fig. 11). If the fissure maintained the same length, roughly $200 \mathrm{~m}$, during both phases, and all the physical parameters remained as above, then the fissure aperture during the $2 \mathrm{~m}^{3} \mathrm{~s}^{-1}$ effusion rate would have been about $0.19 \mathrm{~m}$ (very similar in thickness to the feeder in Fig. 3a). Similarly, during the abrupt increase in effusion rate to $12 \mathrm{~m}^{3} \mathrm{~s}^{-1}$, the fissure aperture would have been about $0.34 \mathrm{~m}$. Thus, an aperture increase by $15 \mathrm{~cm}$ is enough to increase the effusion rate 6-times. This follows from the cubic law (Eq. 1) which shows that if the aperture is increased by a factor of about $1.8(0.34 \mathrm{~m}$ divided by $0.19 \mathrm{~m})$ then the volumetric flow rate (all other parameters remaining constant) should increase by a factor of $(1.8)^{3}$ or about 6 .

All these thickness results for the feeder dyke in the 1991 Hekla eruption are similar to those measured for dykes and inclined sheets in fossil central volcanoes in Iceland (Gudmundsson, 2002). They are also similar to many of the basaltic feeder dykes discussed in the present paper. It should be noted, however, that the thickness estimates for the Hekla 1991 feeder are crude: the magma viscosity and density very likely changed during the eruption, and the depth to the source magma chamber is still poorly constrained - and this depth affects the excess pressure gradient. However, keeping these limitations in mind, the results with regard to feederdyke thickness are very reasonable and in good agreement with the data presented in this papers on feeder dykes from 
Tenerife as well as data on dykes and sheets within eroded central volcanoes in Iceland.

These results do not exclude variations in the excess pressure in the source magma chamber during the eruption. In fact, as indicated above, it follows from Eq. (7) that the magma pressure in the chamber must have been generally declining during the eruption; that is, the excess pressure is theoretically a negative exponential function of time. While magma may flow into the chamber (from a deeper reservoir) during an eruption, it is well documented that the rate of flow through a dyke out of the chamber is normally much faster than the rate of inflow (e.g., Stasiuk et al., 1993; Woods and Huppert, 2003; Gudmundsson, 2002, 2012b). Thus an abrupt increase in volumetric flow rate during an eruption, such was observed in the 1991 Hekla eruption (Fig. 11), is unlikely to be due to a sudden increase in the rate of inflow into the source magma chamber and more likely to be related to changes in the aperture of the feeder dyke.

\section{Discussion}

During a volcanic unrest period with a dyke injection, the associated volcanic hazard depends, to a large degree, on the probability of the dyke reaching the surface to become a feeder. If the dyke becomes arrested on its way to the surface, there will be no eruption and no volcanic hazard in the ordinary sense. However, the dyke emplacement, even if no feeder forms, may trigger earthquakes and possibly landslides that give rise to earthquake and landslide hazards.

Despite studies of hundreds of thousands of dykes worldwide, there are surprisingly few reported feeder dykes, and even fewer that have been studied in any great detail. Perhaps the most detailed previous studies of feeder dykes are those by Geshi et al. (2010, 2012), who made careful measurements of feeder dykes in the 200-m-high caldera walls of the Miyakejima Caldera in Japan and compared them with non-feeders. They show that the geometries of feeders and non-feeders, particularly close to their upper tips, are fundamentally different. In particular, the feeders tend to widen up on reaching the free surface of the earth - the surface of the volcano containing the dyke - whereas non-feeders, understandably, become thinner, that is, taper away, on approaching their upper tips.

Another important result of the studies by Geshi et al. $(2010,2012)$ is that most of the dykes seen are arrested. Even at shallow depths, a few tens of metres below the surface of the caldera, most of the dykes are seen to be arrested. Thus, apparently, few of the dykes make it to the surface to become feeders, even if they reach quite shallow depths. This is in agreement with other studies (e.g., Gudmundsson, 2002; Moran et al., 2011) which indicate that the majority of dykes become arrested on their paths to the surface and thus never become feeders.
There are many possible reasons as to why a propagating dyke becomes arrested rather than reaching the surface to become a feeder. The main reasons, however, relate to the mechanical layering and local stresses in the rock through which the potential feeder dyke has to propagate to reach the surface (e.g., Gudmundsson, 2012a). When the rock layers have contrasting mechanical properties, in particular large differences in Young's modulus, then there is a greater tendency for the dyke to become arrested than if all the layers have similar mechanical properties. This is supported by the many dykes that become arrested at contacts between mechanically dissimilar layers as seen in the caldera walls of Miyakejima (Geshi et al., 2010, 2012). Further support derives from the low proportion of magma supplied to a volcano that is actually erupted during any given period. For example, Harris et al. (2000) estimated that only about $30 \%$ of the magma supplied to the Krafla Volcano in Iceland 1975-1984 was erupted, and only $13 \%$ of the magma supplied to Etna during the period 1980-1995 was erupted. Much of the magma was emplaced in dykes that did not reach the surface.

The results also indicate that in basaltic edifices (shield volcanoes), composed mostly of mechanically very similar layers, the chances of an injected dyke reaching the surface are greater, other things being equal, than in a stratovolcano composed of mechanically dissimilar layers. During unrest periods with dyke injection, the probability of a feeder-dyke formation and eruption are thus normally higher in a shield volcano than in a stratovolcano.

No feeder dyke forms, however, unless there is enough energy to drive the dyke fracture through all the layers of its host rock and to the surface. It can be shown that during common unrest periods with excess pressures reaching the tensile strength of the rock and associated magma-chamber inflation, the stored elastic strain energy is theoretically large enough to propagate a typical basaltic dyke to the surface, thereby generating a feeder (Gudmundsson, 2012a). This assumes a sill-like magma chamber with an excess pressure of 3-4 MPa and chamber inflation on the order of one metre. For unrest periods with much lesser excess pressures and inflations, the strain energy solely due to the magma chamber excess pressure and inflation itself may not be enough to propagate an injected dyke (formed at a lower excess pressure) to the surface. But there are other energy sources in the volcano, such as the work related to volcano spreading and spreading in rift zones. As indicated above, even if the available energy would be theoretically high enough, the dyke has to propagate through all the layers on its way to the surface, many of which would tend to arrest the dyke. Nevertheless, many dykes make it to the surface to form feeders.

Once a feeder reaches the surface, the associated hazards depend much on the volumetric flow or effusion rates (Fig. 11). Commonly, the effusion rates peak very early in the eruption and then fall off exponentially with time (e.g., Machado, 1974; Wadge, 1981; Stasiuk et al., 1993; Thordarson and Self, 1993; Thordarson and Larsen, 2007; Neri et al., 
2011). However, there are many cases where the effusion rate fluctuates so that, in the later stages of the eruption, there is, for a while, an increase in the effusion rate (Fig, 11; e.g., Gudmundsson et al., 2002; Nakada and Motomura, 1999; Harris and Neri, 2002).

It is well known that effusion rates play a fundamental role in deciding the type and lengths of lava flows (Walker, 1973; Calvari et al., 2003; Coppola et al., 2005; Thordarson and Larsen, 2007; Harris and Rowland, 2009), sizes of the cones in the formation of shield volcanoes (Thordarson and Sigmarsson, 2009), and are one of the distinctive differences between summit and flank eruptions on some volcanoes such as Etna (Neri et al., 2011). It follows that effusion rates, and their variations, are of fundamental importance when assessing related hazards.

In some cases increases in effusion rates at later stages of an eruption (Fig. 11) may be attributable to increase in controlling magmatic overpressure in the feeder dyke (e.g., Nakada and Motomura, 1999; Harris and Neri, 2002). This may, for example, come about when different compartments of the source magma chamber begin to supply magma, commonly of somewhat different composition and under different excess pressure, to the feeder dyke (Gudmundsson, $2012 b$ ). Another reason for an abrupt effusion rate change during the later stages of an eruption, as analysed for the 1991 Hekla eruption above, may be an increase in the opening or aperture of the feeder dyke.

\section{Conclusions}

Base on the field observations and theoretical analysis presented in this paper, our main conclusions are as follows:

- Most feeders are sheet-like and sub-vertical. Even if the feeder is inclined at depth, and thus an inclined sheet, it becomes vertical on reaching the surface. This is in agreement with orientation of the principal stresses at free surfaces. In contrast to non-feeders, many feeders are highly vesicular and the number of vesicles increases on approaching the surface. Also, some feeders have elongated, empty cavities or hollows, parallel with the dyke wall and located in the dyke centre.

- On approaching the free surface, many feeders increase their thickness. This is partly because of magma-erosion effects, but mainly because of the free-surface effects; the opening of any extension fracture tends to be greatest at the free surface because the elastic constraints on the opening-displacement are partly removed at that surface (Gudmundsson et al., 2008). This is in excellent agreement with other observations of feeders (Geshi et al., 2010, 2012).

- Further modelling of the mechanical interaction between feeder dykes and faults is of vital importance for assessing hazards and risks of feeder-dyke formation during volcanic unrest periods. One basic aspect of such a model is to help us to understand the conditions that allow magma to flow into, and occasionally up along, fault planes. Hazard modelling involving the interaction between faults and feeder dykes has already been made for volcanoes such as Etna (Cappello et al., 2012).

- The volumetric flow or effusion rate of a feeder dyke commonly reaches its peak very early in the eruption and then declines exponentially with time. There are many examples, however, where the effusion rates increase, sometimes abruptly, at a later stage in the eruption. We analyse the case of the 1991 Hekla eruption in Iceland (Fig. 11). Our results indicate that during the initial peak in the effusion rate the opening (aperture) of the feeder dyke was around $0.77 \mathrm{~m}$. During the subsequent decline in the effusion rate to a minimum, the aperture decrease to about $0.19 \mathrm{~m}$. At the subsequent abrupt increase in the effusion rate, the feederdyke opening may have increased to about $0.34 \mathrm{~m}$, and then decreased again as the effusion rate gradually declined during the end stages of the eruption.

Acknowledgements. We are grateful to the staff of the Teide National Park. This research has been partially supported by a Marie Curie Fellowship (for I. Galindo), contract MEIF-CT2006-0250007, from the European Commission. We also thank Nobuo Geshi and Marco Neri for very helpful review comments that significantly improved the paper.

Edited by: J. Marti

Reviewed by: M. Neri and N. Geshi

\section{References}

Acocella, V. and Neri, M.: What makes flank eruptions? The 2001 Etna eruption and its possible triggering mechanism, B. Volcanol., 65, 517-529, 2003.

Acocella, V. and Neri, M.: Dike propagation in volcanic edifices: overview and possible development, Tectonophysics, 471, 6777, 2009.

Acocella, V., Neri, M., and Sulpizio, R.: Dike propagation within active central volcanic edifices: constraints from SommaVesuvius, Etna and analogue models, B. Volcanol., 71, 219-223, 2009.

Atkinson, S. S. and Lambert, R. J.: The Roza Member feeder dyke system, Columbia River Basalt Group, USA, Compositional variation and emplacement. Mafic dykes and emplacement mechanisms, edited by: Parker, A. J., Rickwood, P. C., and Tucker, D. H., Balkema, Rotterdam, 447-459, 1990.

Bear, J.: Dynamics of Fluids in Porous Media, Elsevier, Amsterdam, 726 pp., 1972.

Bjarnason, I. T.: An Iceland hotspot saga, Jokull, 58, 3-16, 2008.

Blake, S.: Volcanism and the dynamics of open magma chambers, Nature, 289, 783-785, 1981. 
Bonafede, M. and Danesi, S.: Near-field modifications of stress induced by dyke injection at shallow depth, Geophys. J. Int., 130, 435-448, 1997.

Bonafede M. and Olivieri, M.: Displacement and gravity anomaly produced by a shallow vertical dyke in a cohesionless medium, Geophys. J. Int., 123, 639-652, 1995.

Bruce, P. M. and Huppert, H. E.: Thermal control of basaltic fissure eruptions, Nature, 342, 665-667, 1989.

Burke, K.: African plate, S. Afr. J. Geol., 99, 339-409, 1996.

Burke, K. and Wilson, J. T.: Is the African plate stationary?, Nature, 239, 387-389, 1972.

Cappello, A., Neri, M., Acocella, V., Gallo, G., Vicari, A. and Del Negro, C.: Spatial vent opening probability map of Etna volcano (Sicily, Italy), B. Volcanol., 74, 2083-2094, 2012.

Calvari, S., Neri, M., and Pinkerton, H.: Effusion rate estimations during the 1999 summit eruption on Mount Etna, and growth of two distinct lava fields, J. Volcanol. Geoth. Res., 119, 107-123, 2003.

Carracedo, J. C., Day, S., Guillou, H., Rodríguez Badiola, E., Canas, J. A., and Pérez Torrado, F. J.: Hotspot volcanism close to a passive continental margin: the Canary Islands, Geol. Mag., 135, 591-604, 1998.

Coppola, D., Staudacher, T., and Cigolini, C.: The May-July 2003 eruption at Piton de la Fournaise (La Reunion): Volume, effusion rates, and emplacement mechanisms inferred from thermal imaging and Global Positioning System (GPS) Survey, in: Kinematics and Dynamics of Lava Flows, edited by: Manga, M. and Ventura, G., Geol. Soc. Am. Spec. Pap. , 396, 103-124, 2005.

Delaney, P. T. and Gartner, A. E.: Physical processes of shallow mafic dike emplacement near the San Rafael Swell, Utah, Geol. Soc. Am. Bull., 109, 1177-1192, 1997.

Deming, D.: Introduction to Hydrogeology, McGraw-Hill, New York,468 pp., 2002.

Duggen, S., Hoernle, K. A., Hauff, F., Klügel, A., Bouabdellah, M., and Thirlwall, M. F.: Flow of Canary mantle plume material through a subcontinental lithospheric corridor beneath Africa to the Mediterranean, Geology, 37, 283-286, 2009.

Frank, F.: Handbook of the 1350 active volcanoes of the world. Thun, Switzerland, Otto Verlag, 192 pp., 2003 (in German).

Galindo, I.: Estructura volcano-tectónica y emisión difusa de gases de Tenerife (Islas Canarias), Ph.D. thesis, Facultad de Ciencias Geológicas, Universidad de Barcelona, 336 pp., 2005.

Galindo, I., Soriano, C., Marti, J. and Pérez, N.: Graben structure in the Las Cañadas edifice (Tenerife, Canary Islands): implication for active diffuse degassing and insights on the caldera formation, J. Volcanol. Geoth. Res., 144, 73-78, 2005.

Garcia, S., Arnaud, N. O., Angelier, J., Bergerat F., and Homberg, C.: Rift jump process in Northern Iceland since $10 \mathrm{Ma}$ from Ar40/Ar-39 geochronology, Earth. Planet. Sc. Lett., 214, 529-544, 2003.

Geshi, N., Kusumoto, S., and Gudmundsson, A.: Geometric difference between non-feeder and feeder dikes, Geology, 38, 195198, 2010.

Geshi, N., Kusumoto, S., and Gudmundsson, A.: Effects of mechanical layering of host rocks on dike growth and arrest, J. Volcanol. Geoth. Res., 223, 74-82, 2012.

Goto, Y., Gouchi, N., and Itaya, T.: Radial dyke swarms and reconstruction of the Pleistocene submarine volcanoes in the Shiretoko Peninsula, Japan, Mafic dykes and emplacement mechanisms, edited by: Parker, A. J., Rickwood, P. C., and Tucker, D. H., Balkema, Rotterdam, 25-33, 1990.

Gray, T. G. F.: Handbook of crack opening data, Abington Publishing, Cambridge, 96 pp., 1992.

Greenland, L. P., Okamura, A. T., and Stokes, J. B.: Constraints on the mechanics of the eruption, edited by: Wolfe, E. W., in: The Puu Oo Eurption of Kilauea Volcano, Hawaii: Episodes 1 Through 20, January 3, 1983 Through June 8, 1984, US Geol. Surv. Prof. Pap., 1463, 155-164, 1988.

Gudmundsson, A.: Formation of dykes, feeder-dykes, and the intrusion of dykes from magma chambers, B. Volcanol., 47, 537-550, 1986.

Gudmundsson, A.: Emplacement and arrest of sheets and dykes in central volcanoes, J. Volcanol. Geoth. Res., 116, 279-298, 2002.

Gudmundsson, A.: Surface stresses associated with arrested dykes in rift zones: B. Volcanol., 65, 606-619, 2003.

Gudmundsson, A.: Strengths and strain energies of volcanic edifices: implications for eruptions, collapse calderas, and landslides, Nat. Hazards Earth Syst. Sci., 12, 2241-2258, doi:10.5194/nhess-12-2241-2012, 2012a.

Gudmundsson, A.: Magma chambers: Formation, local stresses, excess pressures, and compartments, J. Volcanol. Geoth. Res., 237238, 19-41, 2012b.

Gudmundsson, A., Oskarsson, N., Gronvold, K., Saemundsson, K., Sigurdsson, O., Stefansson, R., Gislason, S. R., Einarsson, P., Brandsdottir, B., Larsen, G., Johannesson, H., and Thordarson, T.: The 1991 eruption of Hekla, Iceland, B. Volcanol., 54, 238246, 1992.

Gudmundsson, A., Friese, N., Galindo, I., and Philipp, S. L.: Dikeinduced reverse faulting in a graben, Geology, 36, 123-126, 2008.

Haimson, B. C. and Rummel, F.: Hydrofracturing stress measurements in the Iceland research drilling project drill hole at Reydarfjordur, Iceland, J. Geophys. Res., 87, 6631-6649, 1982.

Harris, A. J. L. and Neri, M.: Volumetric observations during paroxysmal eruptions at Mount Etna: pressurized drainage of a shallow chamber or pulsed supply?, J. Volcanol. Geoth. Res., 116, 79-95, 2002.

Harris, A. J. L. and Rowland, S. K.: Effusion rate controls on lava flow length and the role of heat loss: a review, in: Studies in Volcanology: the Legacy of George Walker, Special Publication of IAVCEI 2, edited by: Thordarson, T., Self, S., Larsen, G., Rowland, S. K., and Hoskuldsson, A., The Geological Society of London, London, 33-51, 2009.

Harris, A. J. L., Murray, J. B., Aries, S. E., Davies, M. A., Flynn, L. P., Wooster, M. J., Wright, R., and Rothery, D. A.: Effusion rate trends at Etna and their implications for eruptive mechanisms, J. Volcanol. Geotherm. Res., 102, 237-270, 2000.

Hoernle, K. A. J. and Schmincke, H.-U.: The role of partial melting in the 15-Ma geochemical evolution of Gran Canaria: a blob model for the Canary hotspot, J. Petrol., 34, 599-626, 1993.

Jonsson, J.: Jardfraedikort of Reykjanesskaga (Report on the geology of the Reykjanes Peninsula), Orkustofnun, OS-JHD-7831, Reykjavik, 303 pp., 1978 (in Icelandic).

Keating, G. N., Valentine, G. A., Krier, D. J., and Perry, F. V.: Shallow plumbing systems for small-volume basaltic volcanoes, B. Volcanol., 70, 563-582, 2008.

Kilburn, C. J.: Lava flows and flow fields, in: Encyclopedia of Volcanoes, edited by: Sigurdsson, H., Academic Press, New York, 
291-305, 2000.

Klügel, A., Schwarz, S., Bogaard, Pvd., Hoernle, K. A., Wohlgemuth-Ueberwasser, C. C., and Köster, J. J.: Structure and evolution of the volcanic rift zone at São Lourenço peninsula, Madeira, B. Volcanol., 71, 671-685, 2009.

Kusumoto, S., Gudmundsson, A., Simmenes, T. H., Geshi, N., and Philipp, S.: Inverse modeling for estimating fluidoverpressure distributions and stress intensity factors from an arbitrary open-fracture geometry, J. Struct. Geol., doi:10.1016/j.jsg.2012.10.004, in, press, 2012.

Lamb, H.: Hydrodynamics, 6th ed, Cambridge University Press, Cambridge, 1932.

Maaloe, S.: Shape of ascending feeder dikes, and ascend modes of magma, J. Volcanol. Geoth. Res., 81, 207-214, 1998.

Machado, F.: The search for magmatic reservoirs, in: Physical Volcanology, edited by: Civetta, L., Gasparini, P., Luongo, G., and Rapolla, A., 255-273. Elsevier, Amsterdam, 1974.

Marinoni, L. B. and Gudmundsson, A.: Dykes, faults and palaeostresses in the Teno and Anaga massifs of Tenerife (Canary Islands), J. Volcanol. Geoth. Res., 103, 83-103, 2000.

Milne-Thompson, L. M.: Theoretical hydrodynamics, 5th ed. Dover, New York, 1996.

Moran, S. C., Newhall, C., and Roman, D. C.: Failed magmatic eruptions: late-stage cessation of magma ascent, B. Volcanol., 73, 115-122, 2011.

Murase, T. and McBirney, A. R.: Properties of some common igneous rocks and their melts at high temperatures, Geol. Soc. Am. Bull., 84, 3563-3592, 1973.

Nakada, S. and Motomura, Y.: Petrology of the 1991-1995 erupion at Unzen: effusion pulsation and groundmass crystallization, J. Volcanol. Geoth. Res., 89, 173-196, 1999.

Neri, M., Lanzafame, G., and Acocella, V.: Dike emplacement and related hazards in volcanoes with sector collapse: the 2007 Stromboli eruption, J. Geol. Soc. London, 165, 883-886, 2008.

Neri, M., Acocella, V., Behncke, B., Giammanco, S., Mazzarini, F., and Rust, D.: Structural analysis of the eruptive fissures at Mount Etna (Italy), Ann. Geophys., 54, 464-479, 2011, http://www.ann-geophys.net/54/464/2011/.

O'Connor, J. M., Stoffers, P., Van den Boaard, P., and McWilliams, M.: First seamount age evidence for significantly slower African plate motion since 19 to $30 \mathrm{Ma}$., Earth Planet. Sci. Lett., 171, 575-589, 1999.

Poland, M. P., Moats, W. P., and Fink, J. H.: A model for radial dike emplacement in composite cones based on observations from Summer Coon volcano, Colorado, USA, B. Volcanol., 70, 861875, 2008.

Pollard, D. D. and Holzhausen, G.: On the mechanical interaction between a fluid-filled fracture and the earth's surface, Tectonophysics, 5, 27-57, 1979.

Pollard, D. D., Delaney, P. T., Duffield, W. A., Endo, E. T., and Okamura, A. T.: Surface deformation in volcanic rift zones, Tectonophysics, 94, 541-584, 1983.
Rickwood, P. C.: The anatomy of a dyke and the determination of propagation and magma flow direction, in: Mafic Dykes and Emplacement Mechanisms, edited by: Parker, A. J., Rickwood, P. C., and Tucker, D. H., Balkema, Rotterdam, 81-100, 1990.

Rosi, M., Papale, P., Lupi, L., and Stoppato, M.: Volcanoes: Buffalo, Firefly Books, 2003.

Rubin, A. M.: Propagation of magma-filled cracks, Annu. Rev. Earth Pl. Sc., 23, 287-336, 1995.

Rubin, A. M. and Pollard, D. D.: Dike-induced faulting in rift zones, Geology, 16, 413-417, 1988.

Saemundsson, K.: Vulkanismus und tektonid des Hengill-Gebietes in Südwest-Island, Acta Nat. Isl., 2, 1-105, 1967.

Schultz, R. A.: Limits on strength and deformation properties of jointed basaltic rock masses, Rock Mech. Rock Eng., 28, 1-15, 1995.

Siebert, L., Simkin, T., and Kimberly, P.: Volcanoes of the World, 3rd ed. University of California Press, London, 2010.

Simkin, T. and Siebert, L.: Earth's volcanoes and eruptions: an overview, in: Encyclopaedia of Volcanoes, edited by: Sigurdsson, H., New York, Academic Press, 249-261, 2000.

Spera, F. J.: Physical properties of magmas. in: Encyclopedia of Volcanoes, edited by: Sigurdsson, H. Academic Press, New York, 171-190, 2000.

Stasiuk, M. V., Jaupart, C., and Sparks, R. S. J.: On the variation of flow rate in non-explosive lava eruptions, Earth Plantet Sc. Lett., 114, 505-516, 1993.

Thordarson, T. and Larsen, G.: Volcanism in Iceland in historical time: Volcano types, eruption styles and eruptive history, J. Geodyn., 43, 118-152, 2007.

Thordarson, T. and Self, S.: The Laki (Skaftar Fires) and Grimsvotn eruptions in 1783-1785, B. Volcanol., 55, 233-263, 1993.

Thordarson, T. and Sigmarsson, O.: Effusive activity in the 19631967 Surtsey eruption, Iceland: flow emplacement and growth of small lava shields, in: Studies in Volcanology: the Legacy of George Walker, Special Publication of IAVCEI 2, edited by: Thordarson, T., Self, S., Larsen, G., Rowland, S. K., and Hoskuldsson, A., The Geological Society of London, London, 53-84, 2009.

Wadge, G.: The variation of magma discharge during basaltic eruptions, J. Volcanol. Geotherm. Res., 11, 139-168, 1981.

Walker, G. P. L.: Lengths of Lava Flows, Phil. Trans. R. Soc. Lond. A, 274, 107-118, 1973.

Wang, H. F.: Theory of Linear Poroelasticity, Princeton University Press, Princeton, 2000.

Wolfe, C. J., Bjarnason, I. T., VanDecar, J. C., and Solomon, S. C.: Seismic structure of the Iceland mantle plume, Nature, 385, 245247, 1997.

Woods, A. W. and Huppert, H. E.: On magma chamber evolution during slow effusive eruptions, J. Geophys. Res., 108, 2403, doi:10.1029/2002JB002019, 2003. 